$$
\begin{aligned}
& \text { MORTY YEARS NOTES } \\
& \text { OFA } \\
& \text { WIETD ORNITHOLOGIST, } \\
& \text { BY JOHN KRIDER. }
\end{aligned}
$$




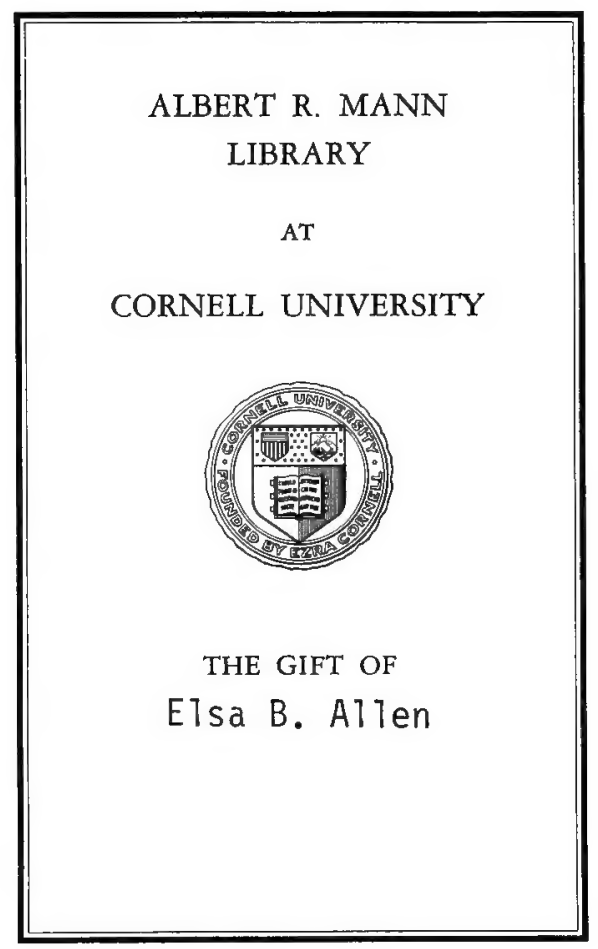


St sa P. Allen xar.24,1947

LABORATORY OF ORNITHOLOGY CORNELL UNIVERSITY
ITHACA, NEW YORK : 


\section{Cornell University Library}

The original of this book is in the Cornell University Library.

There are no known copyright restrictions in the United States on the use of the text.

http://www.archive.org/details/cu31924022533289 

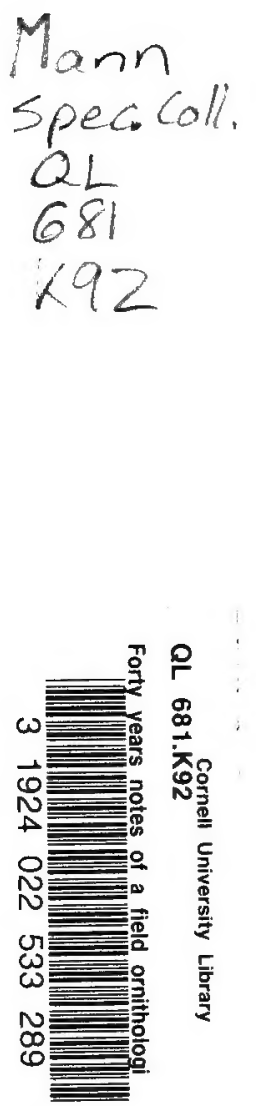

章 



\title{
FORTY YEARS NOTES
}

\author{
OF A
}

\section{FIELD ORNITHOLOGIST,}

\section{BY JOHN KRIDER,}

Mimher of the; Philadelphia ACademy of Natural Sciences, ANI) AUTHOR OF KRIDER'S SPORTING ANECDOTES,

PHILADELPHIA.

GIVING A DESCRIPTION OF ALL BIRDS KILLED AND PREPARED BY HIM.

PHILADELPHIA:

Press or Josefh H. Weston, 438 Walnut S'treet. I879. 


$$
\begin{aligned}
& \text { Mann } \\
& 4 L \\
& \text { Cह } \\
& \text { K92 }
\end{aligned}
$$

$$
392187
$$




\section{PREFACE.}

In offering this little volume to the public, I have endeavored to describe and give the history of only those species of birds of the United States that I have myself collected and mounted, and whose nests and eggs I have located and gathered. In the forty years that I have been occupied in making my several collections, the habits of the birds I include in my notes have become very familiar to me, and having been among them at all seasons of the year, the brief accounts I present for the benefit of the ornithologiss and collector can be relied upon as accurate.

I have endeavored to give, in as plain a manner as possible, such information as will be of value to the collector, setting forth localities where I have usually found the different species and discovered their eggs. All the varieties described in my notes, have come directly under my observation, and of these only do I treat.

JOHN KRIDER. 
Entered, according to Act of Congress, October Irth, 1878, by JOHN KRIDER, in the office of the Librarian of Congress,

at Washington, D. C. 


\section{CONTENTS.}

PAGE

Cathartes Aura. Iltig. Turkey Buzzard......... I Cathartes Atratus. Lesson. Black Vulture........ 2 Falco Inalum. Bonap. Duck Hawk........... 2 Hypotriorihis Columbrius. Gr. Pigeon Hawk... 4 Tinnunculus Sparverius. Tieill. Sparrow Hawk.... 4 Astur Atricupllus. Bonap. Goshawk........... 4 Accipiter Cooperii. Bonap. Cooper's Hawk...... 5 Accipiter Fuscus. Bonap. Sharp-shinned Hawk.... 5 Buteo Borealis. Fieill. Red-tailed Hawk......... 6 Buteo Montanus. Airtull. Western Red-tail...... 7 Buteo Kriderii. Hoopes. Krider's Hawk......... 7 Buteo Lineatus. Jardine. Red-shouldered Hawk... 8 Buleo Pennsylvanicus. Bonap. Broad-winged Hawk. 8 Butel Oxypterus. Cassin. Sharp-winged Hawk.... 9 Archibuteo Lagopus. Gray. Rough-legged Hawk... 9 Archibuteo Sancti-Johannis. Gray. Black Hawk... 9 9 Nauclerus Furcatus. ITigors. Swallow-tailed Hawk. ro Rosthramus Sociabilis. D'Orb. Black Kite...... Io Circus Hudsonicus. Iieillot. Marsh Hawk........ I I Aquila Canadensis. Cassin. G. Eagle; Ring-tail Eagle. I I Haliaetus Leucocephalus. Savigny. Bald Eagle..... I I 
Pandion Carolinensis. Bon. Fish Hawk........ I 2 Strix Pratincola. Bontp. Barn Owl.......... I 3 Bubo Virginianus. Bonap. Great Horned Owl..... I3 Scops Asio. Bonap. Mottled Owl.... ........ $\mathrm{I}_{3}$ Otus Milsonianus. Lesson. Long-eared Owl....... 14 Brachyotus Cassinii. Brezer. Short-eared Owl.... I 5 Syrnium Nebulosum. Gray. Barred Owl........ I 5 Nyctale Arcadia. Bon. Saw-whet Owl.......... I 5 Nyctea Nizea. Gray. Snowy Owl........... I6 Surnia Ulula. Bonap. Hawk Owl... ....... I6 Crotophaga Ani. Linn. Ani.............. I6 Coccygus Americanus. Bonap. Yellow-billed Cuckoo. 17 Coccygus Erythrophthalmus. Bp. Black-billed Cuckoo. I 7 Campephilus Principalis. Gray. Ivory-billed Woodpecker....................... I7 Picus Tillosus. Linn. Hairy Woodpecker........ r 8 Picus Pubescens. Linn. Downy Woodpecker....... I 8 Picus Borealis. Iieill. Red-Cockaded Woodpecker. I 8 Centurus Flaviventris. Sto. Yellow-bellied Woodpecker I 8 IIylotomus Pileatus. Baird. Black Woodpecker..... I 8 Centurus Carolinus. Bonap. Red-bellied Woodpecker. I 9 Melanerpes Erythrocephalus. Sw. Red-headed Wood-

pecker......................... I9

Colaptus Auratus. Swainson. Yellow-shafted Flicker. I9 Trochilus Colubris, Linn. Humming Bird....... 20 Chaturi Pelasgia. Steph. Chimney Swallow...... 20 Antrostomus Vociferus. Bonap. Whip-poor-will.... 20 Chordeiles Pupetue. Baird. Night Hawk........ 20 Chordeiles Henryi. Cassin. Western Night Hawk.. 2 I Ceryle Alcyon. Boie. Belted King-fisher......... $2 \mathbf{I}$ Milvulus Forficatus. Sw. Scissor-tail.......... 2 I Tyrannus Carolinensis. Baird. King Bird; Bee Bird. 22 Tyrannus Dominicensis. Rich. Gray King Bird... 22 Myiarchus Crinitus. Cab. Great-crested Flycatcher. 22 Sayornis Fuscus. Bairl. Pewee............ 22 Contopus Virens. Cab. Wood Pewee.......... 23 
Empidonax Traillii. Baird. Traill's Flycitrler... 23 Empitonax Minimus. Bairt. Least Flycatcher..... 23 Empidonar Acadicus. Baird. Green-crented Flycatcher ....................... 23

Empidonax Flaviventris. Baird. lelluw-bellied Flycatcher........................... 24

Contopus Borealis. Baird. Olive-sided Flycatcher.. 24 Turdus Mustelinus. Gm. Wood 'Ihrush......... 24 Turdus Pallasi. Cab. Hermit Thrush.......... 24 Tullis Fuscescens. Stephens. Wilson's 'Thrush..... 24 Turdus Swainsonii. Cah. Olive-backed 'Thrush.... 25 Turdus Alicice. Baird. Gray-cheeked Thrush..... 25 Turdus Migratorius. Linn. Robin.......... 25 Siatia Sialis. Iraird. Blue Bird............. 25 Resulus Calendulat. Licht. Ruby-crowned Wren... 26 Regulus Satrapa. Licht. Golden-crested Wren.... 26 Anthus Ludoniciunus. Licht. Tit-lark........... 26 Aniotilta lizric. lieill. Black and White Creeper. . 26 Parula Americana. Bonap. Blue Yellow-back...... 27 Geothlypis Trichas. Cat. Maryland Yellow-throat.. 27 Geothlypis Philadelphia. Baird. Mourning Warbler. 27 Geothlypis Mackilliz'ravi. Baird Macgillivray"sWarbler 27 Oporornis Agilis. Baird. Connecticut Warbler.... 28 Oporornis Formasui. Baird. Kentucky Warbler... 28 Icteria Iiridis. Bonap. Yellow-breasted Chat..... 28 Helmitherus Verminorus. Bonap. Worm-eating Warbler 28 Helminthophaga I'inus. Baird. Blue-winged Yellow Warbler.

Helminthophaga Chryoptera. B. Golden-winged Warbler......................... 29

Helminthophaga Ruficapilla. Bd. Nashville Warbler. 29 Helminthophaga Celatt. Baird. Orange-crowned Warbler........................... 29 Helminthophas (a Peregrina. Cab. Tennessee Warbler. 30 Seiurus Aurocapillus. Sw. Golden-crowned Thrush. 30 Seiurus Noveboracensis, Nutt. Water Thrush... 30 
Seiurus Ludonicianus. Bonap. Large-billed Water Thrush........................... 30 Dendroica lirens. Baird. Black-throated Green Warbler......................... 30 Dentroica Canadensis. Batral. Black-throated Blue Warbler...................... 3 1 Dendroica Coronata. Gray. Yellow-rump Warbler. 3 I Dentroica Blackburnue. Baird. Blackburnian Warbler. 3 I Dendroica Castanea. Bairt. Bay-breasted Warbler. $3^{\mathrm{I}}$ Dendroica Pinus. Bairl. Pine-creeping Warbler... $3^{\text {I }}$ Dendroiad Pennsyloanica. Baird. Chestnut-sided

Warbler....................... 32

Dendroica Cantea. Baird. Blue Warbler....... $3^{2}$ Dendroica Striata. Bairl. Black-poll Warbler..... $3^{2}$ Denilroica Aestiza. Baird. Yellow Warbler....... $3^{2}$ Dendroica lfaculosa. Bairt. Blick and Yellow Warbler 33 Dendroica Tigrina. Baird. Cape May Warbler..... 33 Dendroica Palmarum. Bairt. V'ellow Red Poll.... 33 Dendroica Superciliosa. Baird. Yellow-throated Warb'r 33 Dentroica Discolor. Bairl. Prairie Warbler...... 33 Wyiodioctes Mitratus. Aut. Hooded Warbler.... 34 Wyidloctes Pusillus. Bonap. Green Black-cap Flycatcher......................... 34 Mviodiuctes Canadensis. Aud. Canada Flycatcher... 34 Setophaga Ruticilla. Sze. Redstart........... 34 Puranire Rubra. Vieill. Scarlet Tanager......... 34 Pyranga Aestiva. lieill. Summer Red Bird..... 35 Flirmilo Horreorum. Barton. Barn Swallow..... 35 Ilinundo Lunifrons. Say. Cliff Swallow......... 35 llirundo Bibolor. Ticill. White-bellied Swallow.... 35 Cotyle Riparia. Boic. Bank Swallow......... 35 Cotyle Serripennis. P'onap. Rough-winged Swallow.. $3^{6}$ Progne Purpurea. Boie. Purple Martin......... $3^{6}$

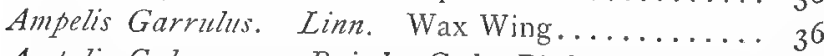
Ampelis Cedronum. Baird. Cedar Bird........... $3^{6}$ Collyrio Borealis. Baird. Great Northern Shrike... 37 
Collyrio Lutonicianus. Baird. Loggerhead Shrike.. 37 Collyrio Excubitoroides. Baird. White-rumped Shrike...................... 37

Vireo Olivaceus. Vieill. Red-eyed Flycatcher..... 37 Vireo Altiloquus. Gray. Whip Tom Kelly....... $3^{8}$ Vireo Philadelphicus. Cassin. Philadelphia Vireo... $3_{3}^{8}$ Irreo Gilwus. Bonap. Warbling Flycatcher...... 38 Vireo Noveboracensis. Bonap. White-eyed Vireo... 38 Vireo Solitarius. Fieill. Blue-headed Flycatcher... 38 Vireo Flavifrons. Vieill. Yellow-throated Flycatcher 39 Mimus Polyglottus. Boie. Mocking Bird......... 39 llimus Carolinensus. Gray. Cat Bird.......... 39 Harporhynchus Rufus. Cab. Brown Thrush..... 39 Thryothorus Iudovicianus. Bonap. Great Carolina Wrun ...................... 39 Thryothorus Bezickii. 'Bonap. Bewick's Wren.... 40 Cistothmos Palustris, Cab. Long-billed Marsh Vren ..................... 40 Cistothorus Stellaris. Cab. Short-billed Marsh IVren. 40 Troglodytes Aedon. Vieill. House Wren......... 40 Trogludytes Parkmanni. All. P.urkman's Wren... 40 Troglorlytes Hyemalis. Vieill. Winter Wren...... 4I Certhia Anrikana. Bonap. Imerican Creeper.... 4I Sitta Carolinensis. Gmelin. White-bellied Nuthatch. 4 I Sitta Canadensis. Linn. Red-bellied Nuthatch..... 4 I Sitta Pusilla. Latham. Brown-headed Nuthatch.... +4 Polioplita Carulea. Sclat. Blue-gray Gnatcatcher... 42 Lephophanes Biculor. Bonap. Tufted Titmouse...: 42 Parus Atricapillus. Linn. Black-cap Titmouse.... 42 Parus Carolinensis. Aud. Carolina Titmouse..... 43 Eremophila. Cornuta. Boie. Sky Lark........ +3 Pinicola Canallnsis. Cab. Pine Grosbeak........ 43 Carpodacus Purpureus. Gray. Purple Finch..... 43 Chrysomitris Tristis. Bonap, Yellow Bird...... 44 Chrysomitris Pinus. Bonap. Pine Finch........ 44 Curvirostra Americana. Wils. Red Crossbill..... 44 
Curvirostra Lencoptera. Ilits. White-winged Cross-

bill. ......................... 44

Aesiothus Linaria, Cab. Lesser Red Poll........ 45

Plectrophanes Nizalis. Meyer. Snow Bunting..... 45

Plectrophanes Lapponicus. Selby. Lapland Longspur. 45

Passerculus Savanna. Bonap. Savannah Sparrow... 45

Pooecetes Gramineus. Bairl. Grass Finch.. ... 46

Coturniculus Passerinus. Bonap. Yellow-winged

Sparrow....................... 46

Ammodromus Cinducutus. Sze. Sharp-tailed Finch. $4^{6}$

Ammodramus Marritimus. Su. Sea-side Finch.... 46

Zonotrichia Leucophrys. Sw. White-crowned Spar- 46

row ....................... $\ldots \ldots$

Zonotricliti Gambelli. Gambel. Gambel's Finch.... 47

Zonotrichia Coronata. Ba. Golden-crowned Sparrow. 47

Zonotrichia Querula. Gamb. Harris' Finch...... 47

Zonotrichice Albicollis. Bonap. White-throated Spar-

row ......................... 47

Junco Hyemalis. Sclat. Black Snow Bird........ 48

Spisella Monticola. Baird. Tree Sparrow........ 48

Spizella Pusilla. Bonap. Field Sparrow.......... 48

Spizella Socialis. Bonap. Chipping Sparrow...... 48

Spizella Pallida. Bonap. Clay-colored Bunting..... 48

Melospiza . Mrlotha. Baird, Song Sparrow........ 49

Melospiza Lincolnii. Baird. Lincoln's Finch..... 49

.Melospiza Palustris. Baird. Siwamp Sparrow...... 49

Passerelle Iliaca. Sw. Fox-colored Sparrow.. . . 49

Calamospiza Bicolor. Bonap. Lark Bunting...... 49

Euspiza Americana. Bonap. Black-throated Bunting. 49

Guiraca Linlovizitnt. Sa'. Rose-breasted Grosbeak. 5ó

Guiraca Camlea. Sw. Blue Grosbeak.......... 50

Cyanospiza Ciris. Baird. Painted Bunting....... 50

Cyanospiza Cyaned. Baird. Indigo Bird........ 50

Carlinalis Tirginianus. Bonap. Red Bird....... 50

Pipito Erythropthalmus. Vieill. Ground Robin;

Towhee ..................... 5 I 
Dolichonyx Oryzizorus. Sze. Boblink; Reed Bird. 5 I Molothrus Pecoris. Ste. Cow Bird............ 5 I Agelains Phu'niceus. Vieill. Red-winged Black Bird. $5^{1}$ Xanthocephalus Icterocephal's. Yellow-headed Black-

bird.

Sturnellit Magne. Sze. Meaduw Lark.......... 52

Sturnella Nislectu. Aut. Western Lark.... .... 52

litems Spurius. Bunap. Orchard Oriole........ 52

leterus Ballimue. Daudin. Baltimore Oriole..... 52

Scolecophagus Ferrugineus. Sw'. Rusty Blackbird. 5.3

Quiscalus Litior. Tieill. Boat-tailed Grakle...... 53

Quiscalus Tersicolor. Tieill. Crow Blackbird..... 53

Cornus Carnizurus. Bartram. American Raven... 54

Corvill Americanus. Aud. Common Crow..... . 54

Corvus Ossifragus. Wilson. Fish Crow.... ... 54

Pica Hudsonica. Bonat. Magpie........... 54

Cyamura Cristata. Sü. Blue Jay............ 55

Ectopistes lfirraturit. Sw. Wild Pigeon......... 55

Zenaidura Carolinensis. Bonap. Common Dove.. 55

Chamapelia Passerina. Sto. Ground Dove....... 55

Melearris Galloparo. Iim. Wild Turkey....... 56

Tetrao Canadensis. Jinn. Spruce Partridge...... 56

Pedioecetes Phasianellus. Baird. Sluarp-tililed Grouse. 56 Cupildonia Cupido. Baipd. Prairie Hen......... 56 Bontsa Umbellus. Steph. Ruffed Grouse......... $5^{6}$ Iir. Banasa Umbelloilles. Baird. Gray Mountain

Grouse..................... 57

Ortvx Virginianius. Bonaf. Partridge; Quail.... 57

Grus Americanus. Ord. Whooping Crane....... 57

Grus Canadensis. Temm. Sand-hill Crane...... 57

Dimieryetta Luduriatana. Baird. Louisiania Heron. $5^{8}$ Garatta Candidissimar. Bonap. Snowy Heron... 58 Herodias Egretta. Gray. White Heron......... $5^{8}$ Ardea Herodias. Linn. Great Blue Heron....... 58 Florida Caruled. Rarirl. Blue Heron.......... 59 Ardetta Exilis. Gray. Least Bittern......... 59 
Botaurus Lentiginosus. Steph. Bittern; Stake Driver. 59 Butorides lirescens. Bonap. Green Heron..... 59 Nyctiardea Garden. Baird. Night Iferon....... 59 Ibis Alba. Vieillot. White Ibis.............. 60 Ibis Orilit. Bonap. Glossy Ibis............ 60 Phaniopterts Ruber. Linn. Flamingo........ 60 Charatrius Virginicus. Borck. Golden Plover.... 60 Acqualitis lociferus. Cassin. Killdeer... ......60 60 Aegralitis IVilsonus Cassin. Wilson's Plover......6 6I Aegialitis: Semifalmatus. Cab. Semipalmated Plover. 6I Aegralitis Melodus. Cab. Piping Plover.......... 6 $\mathbf{I}$ Squaturola Helvetica. Cur. Black-bellied Plover... 6I Haematopus Palliatus. Temm. Oyster Catcher..... 6r Strepsilas Interpres. Illig. 'Turnstone......... 62 Recurvirostra Americana. Gm. American Avoset.. 62 Himantopurs Nigricollis. Vieillot. Black-necked Stilt. 62 Phalaropus IIitsonii. Sah. Wilson's Phalarope.... 62 Phalaropus Fulicarius. Bonap. Red Phalarope.... $6_{3}$ Philohela Ainur. Gray. Imerican Woodcork.... $6_{3}$ Gallinayo Irisonit. Bonap. English Snipe...... $6_{3}$ . Warorhamphus Griscus. Leach. Red-breasted

Snipe....... ....... .......... $6_{3}$ Macrorhamphus, Scolopaceus. La. Greater Longbeak 64 Tringra Canutus, Linn. Knot... .......... 64 Tringa lhatima. Brunnich. Purple Sand-piper... 64 Tring Alpina, zur. Americana. Cas. Red-backed Sand-piper ....................... $66_{4}$ Tringa Maculata. Vieill. Jack Snipe.......... 64 Tringr IIilsonit. Nuttall. Least Sand-piper...... $6_{5}$ Tringa Bonapartii. Schlegel. Bonaparte's Sand-piper. $6_{5}$ Calidris Arenaria. Illiger. Sinderling......... 65 Fremetes, Petrificatus. Ill. Semipalmated Sandpiper... ...................... . . 65 Gambetta Melanoleuca, Bonap. Tell-tale; Stone

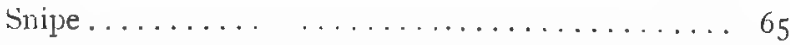
Gambetta Flavipes. Bonap. Yellow Legs......... 66 
Rhryacophilus Solitarius. Bonap. Solitary Sandpiper 66 Tringoiles Macularius. Gray. Spotted Sand-piper.. 66 Actiturus Bartramius. Bonap. Field Plover...... 66 Tryngites Rufescens. Cab. Buff-breasted sand-piper. 67 Limosa Fedoa. Ord. Marbled Godwit..........67 Limosa Hudsonica. Sie. Hudson Godwit........67 Numenius Longirostris. Wils. Long-billed Curlew 67 Numenius Hudsonicus. Latham. Iudsonian Cirlew. 67 Numenius Borealis. Latham. Esquimuux Curlew.. 68 Rallus Elegrans. Aud. Marsh Hen............ 68 Rallus Crepitans. Gm. Clapper Rail.......... 68 Rallus Virginianus. Linn. Virginia Rail........66 Porzana Carolina. Vieill. Common Rail........ 69 Porzana Jamaicensis. Cassin. Little Black Rail.... 69 Porzana Noveboracensis. Yellow Rail........... 69 Crex Pratensis. Bechst. Corn-crake.......... 69 Fulica Americana. Gmelin. Coot............. 70 Gallinula Galeata. Bonap. Florida Gallinule..... 70 Gallinula Martinica. Lath. Purple Gallinule..... 70 Cygnus Americanus. Sharpless. American Swan... 70 Cygnus Buccinator. Rich. Trumpeter Swan...... 70 Anser Hyperboreus. Pallas. Snow Goose....... $7 \mathbf{1}$ Anser Gambelii. Hartlaub. White-fronted Goose.. 71 Bernicla Canatensis. Boie. Canada Goose....... $7 \mathbf{I}$ Bernicla Brenta. Steph. Brant........... $7 \mathbf{I}$ Bernicla Nigricans. Cassin. Black Brant....... 71 Anas Boschas. Linn. Mallard............. 72 Anas Obscura. Gm. Black Duck........... $7^{2}$ Dafila Acuta. Jenyns. Sprig-tail; Pin-tail....... 72 Nettion Carolinensis. Bairl. Green-winged Teal... 72 Nettion Crecca. Kaup. English Teal........ $7^{2}$ Querquedula Discors. Steph. Blue-winged Teal... 72 Spatula Clypeata. Boie. Shoveller........... 73 Chaulelasmus Streperus. Gray. Gadwall........ 73 Mareca Americana. Stephens. Baldpate......... 73 Mareca Penelope. Bonap. Widgeon.......... 73 
PAGE

Aix Sponsa. Boie. Summer Duck........... 73 Fulix Marlit. Baird. Greater Black-head....... 74 Fulix Affinis. Baird. Little Black-head... ..... 74 Fulix Collaris. Baird. Ring-necked Duck....... 74 Aythya Americana. Bonap. Red-head.......... 74 Aythy Thallisneria. Bonap. Canvass-back........ 74 Bucephala Americana. Baird. Golden-Eye....... 75 Bucchlala Alheola. Baird. Butter Ball........ 75 IIarelda Glacialis. Leach. South Southerly...... 75 Melanetta I'lertina. Baird. Velvet Duck........ 75 Prlionetha Eirstithata. Kanp. Surf Duck....... $7^{6}$ Oitrmia Americana. Szoains. Scoter........... 76 Smatria Mollissima. Lcach. Eider Duck....... 76 Simateria Spictalilis. ficth. Kirg Fider....... $7^{6}$ Erismatur Rubida. Bonap. Ruddy Duck....... 77 Merrus Americanus. Cass. Sheldrake......... 77 Morus Serrator. Linn. Red-breasted Merganser... 77

- Lophodytes Cucullutus. Reich. Hooded Merganser. 77 Pelectmus Fuscus. Limn. Brown Pelican........ 77 Pilciamus Erythrorhynchus. Gm. American Pelican. 78 Sila Fassana. Briss. Gannet............ 78 Tichupetes Aquila. Vieillot. Man-of-war Bird..... 78 Graculus Carbo. Gray. Common Cormorant..... 78 Graculus Cincinnatus. Gray'. Tufted Cormorant... 78 Thalassitroma Ililsom. Bonap. Wilson's Petrel... 79 Thalassidroma Pelagica. Bonap. Mother Cary's Chickens...................... 79

Stercorarius Pomarinus. Temm. Pomarine Skua... 79 Larus Marinus. Linn. Great Black-backed Gull... 79 Larus Arsentatus. Brunn. Herring Gull....... 80 Larus Diluaturensis. Ord. Ring-billed Gull..... 80 Chroicocethalus Atricilla. Linn. Laughing Gull... . 8o Chroicocephalus Philadelphia. Bonaparte's Gull.... 80 Sternia Resiat. Gamlit. Royal Tern........... 80 Sterna Fuliginosa. Gm. Sooty Tern.......... 81 Sterna Aranea. Wils. Marsh Tern............ 8I 
PAGE

Sterna Titsoni. Bonap. Wilson's Tern......... $\delta_{1}$ Sterna forsteri. Nutt. Furster's Tern.......... 81 Sterna Paralista. Brmn. Roseate Tern........ 8 I Sterna Frencita. Gimhlile. Least Tern........... 82 Hydrochelidon Plumbea. Wils. Short-tailed 'Tern.. 82 Anous Stolidus. Leach. Noddy Tern..... .... 82 Rhynchops Nigra. Linn. lilack Skimmer.. ..... 82 Colymbus Torquates. Brunn. Loon.......... 82 Colymlmi Septentrionalis. Linn. Red-throated Ijver. $8_{3}$ Podiceps Griseigena Gray. Red-necked Grebe... $8_{3}$ Podiceps Cristatus. Lath. Crested Grebe........ 83 Podiceps Cornutus. Latham. Horned Grebe..... $8_{3}$ Podilymhiss Porliceps. Laur. Carolina Grebe..... 84 Uria Gryllr. Latham. Black Guillemot......... 84 Uria Arra. Pallas. Thick-billed Guillemot ..... 84 Mergului Alle. lieillot. Sea Dove........... 84 



\section{ORNITHOLOGY.}

Cathartes Aura.-Illig.

\section{Turkey Buzzard.}

$\stackrel{\ddagger}{ \pm}$ HIS bird I have found on many of my ex1.1 cursions in Pennsyliania, New Jersey, Delaware and Virginia, and as far west as Iowa. I have never met with them farther nor th than Pennsylvania. I have found it breeding in $\mathrm{New}$ Jersey, Delaware, Virginia and Iowa. Its nest is made of old rotten stumps and logs at all times, and I have never found more than two eggs in a nest. The nest is made of rotten wood and dry leaves, and I have sometimes found but one egg, and several times have found but one young bird in the nest. I have seen more than two hundred of these birds at once on the body of a dead horse, and in less than thirty minutes there was nothing left but the bones. Specimens of both birds and eggs are in my collection.

It is common in all of the above States. 
Cathartes Atratus.-Lesson.

\section{Black Vulture.}

Very common in the Southern States; I have never met with it farther north than North Carolina. I have seen these birds in great numbers on the tops of houses, and in the marketplaces of Charleston, South Carolina; it is a constant visitor to the slaughter-houses about killing-time, looking for the offal. I have found it breeding at Key West, Florida, and its nesi was made the same as Cathartes Aurx, but in a hollow stump, surrounded by cactus bushes, and on my approaching the nest to get the eggs, which were two in number, the old bird made a dart at me as if she wanted to frighten me off, but finding that she could not succeed in that, she threw up a great quantity of carrion, which came very near getting on me; its smell was very disagreeable, but notwithstanding all this, I procured the eggs and both of the birds for my collection. This bird breeds very abundant around the wooded swamps of Charleston, South Carolina.

\section{Duck Hawk.}

$$
\text { Falcon Anctum.-Bonap. }
$$

It is well-known to all the duck-shooters along the flats of the Susquehanna River, as well also to those who frequent the seashore, where this bird is certain to be found during the ducking season. I have found it also on several occasions on the Delaware River, when I was rail-shooting. 
I shot one specimen below the Navy Yard, also another on Jersey shore, both of which had been feeding on some farmer's chickens. I have often noticed the maneuvres of this voracious hero of the falcon tribe, when in pursuit of ducks. On one occasion I was seated in a blind with my decoys in a pond in front of me, waiting for the approach of ducks, when at a distance I saw a small lot of ducks making for the pond. As they approached, I discovered that they were pursued by a hawk, and as soon as they arrived at the edge of the pond they immediately dove under the water. The hawk, somewhat disappointed, continued on his course toward my decoys, making a quick dart and catching one in his talons, but, finding it much heavier than he supposed, soon dropped it, and was in a hurry to get off, when the leaden messengers from my gun brought him down. This specimen is now in the Academy of Natural Sciences, of Philadelphia. I have frequently found this bird along the seashore in Spring, but never found it breeding in that neighborhood which has been so reported. I do not consider it rare, but difficult to obtain. They vary much in size-the male is much smaller than the female, and the-plumage of the adult bird different from that of the young. I have met this bird as far east as Maine, and as far west as Minnesota, along the Mississippi river, and have not been able myself to find its nest, but have the eggs in my collection which were 
found in the State of Maine. I also have the birds which were shot along the Delaware river below Philadelphia.

\section{Hypotriorchis Columbarizs - Gr.}

\section{Pigeon Hawk.}

This spirited little hawk I have found from Maine to Florida, and as far west as Minnesota. It is very abundant in the spring and autumn; I have seen as many as twelve at one time on the fences in lowa, and they are very plenty along the Mississippi river on the rocks and cliffs, but I have never found it breeding Its color is very much like Falco Anatum, and varys in size the same.

\section{Timnunculus Sparverius.-Vieill.}

\section{Sparrow Hawk.}

This pretty little haw is very plenty in all parts of the country that I have been in. I have found it breeding in Maine, and as far west as Minnesota; it feeds mostly on small birds, such as sparrows and warblers. It remains with us all winter. I have never found it breeding farther south than Virginia, but have shot the bird in the month of May, in Florida. Nests in hollow trees-four to six eggs

$$
\text { Hstur Atricapillus.-Bonap. }
$$

\section{Goshawk.}

The Goshawk is considered by some collectors a rare bird, but as I had at one time as many as 
six, and have collected in one scason, twelve birds, I cio not think it rare, but some seasons they do not make their appearance before autumn. I have shot them mostly near a barn, and found them to contain chickens in their crops. I have also found them plenty in Virginia, wher hunting quail, on which they also feed. I have never found the nest, but think it breeds in the high timber in Minnesota, as I have met the bird while shooting prairic chickens in the month of August. I have the eggs in my collection, obtained in the British settlements.

\section{lccipiter Cooperii.-Bonap.}

\section{Cooper's Hawk.}

It is quite a common bird all over the country. I have killed it at all seasons; it is very plenty in Virginia and Iowa, and feeds on quail, young prairie chickens and meadow larks. I have dissected them and found these birds in them scarcely digested. I have been shooting quail and seen this hawk chase a wounded bird until it reached some thicket, when I have gone and picked the bird up. It breeds in New Jersey, and as far west as Iowa, and builds its nest on trees and rocks.

$$
\text { Accipitcr Fuscus.-Bonap. }
$$

\section{Sharp-shinned Hawk.}

It is considered among gunners a bird hawk. I have seen it catch birds while I was shooting 
rail on the marshes of the Delaware River, and have seen it catch rail and reed birds, and I have killed it in the act. It is a very common bird, and found over the whole country. I have found it in Maine and as far west as Minnesota; it keeps in thick timber in breeding season; I have found two nests in a day not more than thirty feet apart, on small pine trees; one of the nests contained eight, and the other six eggs, and I have often found them with five; I have also found its nest built on high rocks in the mountains of Pennsylvania. The male is much smaller than the female, and in some cases the latter is twice the size.

\section{Buteo Borealis.-Vieill.}

\section{Red-tailed Hawk.}

It is generally called the hen-hawk, and is widely distributed over the country. I find it in all parts I have visited, and find it breeding in all heavy timber country. It is very abundant in the winter, about or near Philadelphia, as I have obtained as high as fifty specimens in one season. The young bird is thought by some to be a separate bird, owing to the tail being barred instead of red, as in the old birds. I have found it very plenty in the western country, where it feeds mostly on prairie chickens-also on frogs, snakes and mice. I have seen it pursue a rabbit and devour the most of it at a meal, after which it is easily approached and shot. Nests on trees; eggs four in number. 


\section{Buteo Montanus.-Nuttall.}

\section{Western Red-tail.}

It is a variety of Butio Borealis, but much larger in size, its legs stouter and stronger built, and is found in the mountains west of the Mississippi. Its habits are much the same as the above, and it feeds on hares, gophers and prairie chickens. Eggs four in number; nests on large trees and on the cliffs, and is very hard to get at.

\section{Krider's Hawk.}

\section{Buteo Kriderii-Hoopes.}

It is called by Baird the white red-tail. This bird I have found in Winnebago County, Iowa, in 1870. I first observed it flying at a distance, and at first took it for an albino, but seeing several of them in company together, was very' anxious to procure one. They were very shy, so much so that I could not get near them. As they feed on chickens and other birds, I was able to get one that was shot by Mr. Hill, a farmer in the county. It was shot near his barn while looking after his chickens or pigeons. The second specimen I saw in a different neighborhood, and approached it as I was riding by in a wagon, near sundown; the bird was watching a flock of prairie chickens. The third specimen I obtained in 1873 , in the same county, and in 1874 I found in the same place quite a number, but could not 
get near them. I traced this bird as far west as Fergus Falls, Minnesota, where I procured two eggs; I found its nest on tall pines, and built of sticks, lined with grass and sheeps' wool. The first two specimens are in the Academy of Natural Sciences, of Philadelphia, and the third is in my collection-also the eggs. This bird was described and named by Bernard A. Hoopes, Esq. I obtained another very beautiful specimen in full plumage, from Winnebago Co., Iowa.

\section{Buteo Lineatus.-Fardinc.}

\section{Red-shouldered Hawk.}

It is a rery common bird from Maine to Florida, and west to Minnesota, and I have found it breeding at all these places. I found the first nest in New Jersey, with two young birds and one egg, and the following season I found in the same nest four eggs, and the year after, I found three more eggs in the same nest; but as the place became settled the birds did not appear afterwards.

\section{Butco Penzsylianicus.-Bonat.}

\section{Broad-winged Hawk.}

It is as most of the preceding, very abundant in all parts of the country; more plenty in Autumn, and I found it very plenty in Iowa; never found it breeding there, but have in New Yrork, New Jersey and in the mountain regions of Pennsylvania. Nests on trees-four eggs. 


\section{Buteo Oxypterus-Cassin.}

\section{Sharp-winged Hawk.}

This Hawk was many years ago, and is now very plenty in Iowa. I think it is a variety of the Broad Wing, being found in company with them, and having habits much the same. It feeds on gophers, mice, squirrels, frogs and lizards.

$$
\text { Archibuteo Lagopus-Gray. }
$$

\section{Rough-legged Hawk.}

It was many years ago one of the most abundant of the hawk tribe that we had in the neighborhood of Philadelphia. I have counted as many as twenty at one time in the meadows below the city, but now you can scarcely see one. The railroads running night and day has driven them to some more remote place. I have never found its nest, but have the eggs collected in the fur countries. I have met with it in lowa and along the Mississippi ; it feeds mostly on meadow mice and gophers.

\section{Archibutco Sancti-Foluannis.-Gray'.}

\section{Black Hawk.}

It is considered by some collectors a very rare bird. I have found it the same as most of hawks. It is more plenty some seasons than others. 1 have seen as many as ten at one time in the meadows below the City of Philadelphia, and have obtained eight in one season. 'They appear about October and leave in March; I have found 
this bird breeding in New Jersey in a cedar swamp, the nest being built much the same as the Red-shouldered Hawk, on an old pine tree; the bird was very shy, and I could not obtain it. I have also found this bird as far west as Minnesota, but not breeding there. Have found it in Maryland, but do not consider it rare, still it is not as plenty as years ago, on account of the country settling.

\section{Nauclerus Furcatus.-ITigors.}

\section{Swallow-tailed Hawk.}

It was considered by all collectors the most rare of all hawks, and is now sought after more than any other. I have found it very abundarit in Iowa, Minnesota and Kansas, where they breed; have shot them in Philadelphia and in New Jersey. The first nest I found was at Coon Lake, Iowa ; I watched the bird building, and only obtained one egg, which is now in the Smithsonian Institute, Washington, D. C.

\section{Rosthramus Sociabilis. - D' Orb.}

\section{Black Kite.}

It is found in Florida. Dr. Herman and myself saw several of them soaring at a distance, but could not get near them for some time. I did manage to shoot two specimens, and I think they were young birds; did not see the nest, but think they must breed there, as the specimens we obtained were near the timbered country and in the month of May. 


\section{Circus Hudsonicus.-Vieillot.}

\section{Marsh Hawk.}

This is the most common of all hawks in every part of the country. I have found it breeding on the salt meadows of New Jersey, the nest made of grass and sea-weed, and built on the ground at the side of a lot of bushes. I nave also found it breeding very abundant on the prairies of lowa, its nest being generally at the side of some bushes.

\section{Aquila Cinurdonsis.-Cassin.}

\section{Golden Eagle; Ring-tailed Eagle.}

This is a beautiful bird in full plumage, but 1 have never met with many with that plumage. Those that I have seen are mostly young birds in Fall plumage. I have found them in New Jersey and as far west as the Mississippi River, but I have never found the nest. I have killed it near the farm-yard while it was watching chickens, on which it feeds.

\section{Haliactus Leucocephalus.-Savigny.}

\section{Bald Eagle.}

The Bald Eagle is very plenty along the coast of Virginia, Delaware and New Jersey. It feeds on ducks and fish. I have seen this bird sit on the meadows and watch the fish-hawk catch a fish, when he would pursue the hawk and make him drop his food, and before the fish could reach the water the eagle would catch it and make for 
some secluded spot to feed upon it. I have also seen them chase crippled clucks and make a meal off of them; they frequent mostly the ducking grounds. I have seen them very plenty in the Western States, and on the lakes where the ducks breed. I have found them breeding in New Jersey, near Beesley's Point, also on the the eastern shores of Maryland, and ia Iowa and Minnesota, but have never found more than two eggs in a nest. The young in the Fall plumage is without the white head and tail, and sometimes is very dark, almost black, varying very much in size. I had one from Beesley's Point that measured eight feet, six inches from tip to tip; then I have had them that only measured five feet, six inches. I have seen them in company with the Turkey Buzzard, feeding on the carcasses of dead horses and other dead animals. They build their nests on high trees and cliffs-eggs four in number.

\section{Pandion Carolinesis.-Bon.}

\section{Fish Hawk.}

The Fish Hawk arrives with us in the month of March, and is looked upon as a welcome visitor; it breeds along the coast from New Jersey southward, and is very seldom seen in the inland. I have seen but one specimen in the western country, and that was on the Mississippi River. It is not as plenty along the coast of New Jersey since the establishing of watering- 
places on the island, but farther south you will find it more abundant. Its nest is made of sticks, lined with moss or sea-weed-eggs four in number.

\section{Barn Owl.}

Strix Pratincola.-Bonap.

This owl is found in the Spring and Fall, and breeds in hollow trees. I have found it breeding in the meadows below Gray's Ferry, along the Schuylkill River, in a willow tree, and also found a nest on Smith's Island, opposite the City of Philadelphia, where I procured four birds about half-grown. I have never met them in the West; they are not considered rare.

\section{Bubo Virginianus.-Bonap.}

\section{Great Horned Owl.}

This owl is found all over the country, and some seasons it will be found more plenty than others, owing to the coldness of the weather. I find in the western country that the bird is larger and of a lighter color than in the eastern country. The winter birds of Minnesota are about half white; I found it breeding in Iowa; nest in a hollow tree-eggs four in number; very abundant.

\section{Mottled Owl.}

$$
\text { Scops Asio.-Bonap. }
$$

This bird is very common all over the United States, and varys much in size and plumage. I 
have found it in Iowa in the Spring, it being much smaller than the Eastern bird. I have never found any such red specimens in the West, as I found in the South and East; it is hard to decide whether the male and female are a different specie or not. I see no difference in the marking of the Eastern specimen from the Western, only the size. The eggs are the same color and shape, and the plumage sometimes red, being lighter, but as a general thing the same. It breeds in hollow trees, and is found breeding in apple orchards and the dwellings of farm houses. I found it in a hole in an old barn, and it was very tame. It would let one handle and caress it without leaving the nest. I have found six eggs in one nest, but more frequently four; I have kept them alive for several days and fed them on birds, which they would eat only when no person was watching them.

\section{Otus Wilsonianus:-Lesson.}

\section{Long-eared Owl.}

The Long-eared $\mathrm{Owl}$ is common in the State of Pennsylvania and New Jersey, but I never found it very plenty in Iowa or Minnesota. It can be found in the Winter, mostly in the daytime, in the tops of thick cedar trees. It is more plenty some seasons than others. It feeds on mice. 
Brachyotus Cassinii.-Brewer.

\section{Short-eared Owl.}

This owl is most common of all owls. It can be found all over the country, having found it South, East and West. It makes its nest on the ground, and feeds on meat in the winter, and in the Spring I have found it to contain frogs and ground squirrels. Four eggs.

\section{Syminm Nebulosum.-Gray.}

\section{Barred Owl.}

This owl can be found very plenty in the Eastern and Southern States. It is not very plenty in the West. I have found it breeding in lowa, Delaware and New Jersey. Eggs four in number. I have seen the bird at sundown come from its roost in search of food, and on one occasion it chased a wounded quail; it was so intent after it that it did not notice me, so I killed the owl and caught the quail. I noticed a great difference in the size of this bird. In the winter of 1875 they were more abundant than I ever have seen them.

$$
\text { Nyctale Arcadia.-Bon. }
$$

\section{Saw-whet Owl.}

This is a rare bird and is not often obtained. I have found it in New Jersey and Pennsylvania. I have had it sent to me from Iowa in the Winter, in the flesh. I see no difference in them from those of the Eastern States. It breeds in hollow 
trees; I. found a nest in Iowa with three eggs, also a nest in New Jersey with three eggs.

$$
\text { Nyctea Nivea.-Gray. }
$$

\section{Snowy Owl.}

This owl is a visitor from the northern regions, and it only makes its appearance when the weather is very cold. Some winters it is very scarce, and only one or two specimens can be obtained. I have seen it so plenty in some seasons, that I procured as many as twenty or thirty specimens. It keeps along the coast of the Delaware River, and feeds on birds and mice; I killed one on League Island, on a hammock of ice, and found upon dissecting it, to contain the body of a meadow lark. I have had it from Iowa as late in the Spring as April, and I supposed it to be returning to the North. I have seen it as far south as Virginia, along the shores of the Accomac; it was plenty in the year of 1875 .

\section{Surnia Ulula.-Bonap.}

\section{Hawk Owl.}

The Hawk Owl is very rare with us, as I have never had but one killed in Philadelphia. I have met with it in the State of Maine, where it is more plenty in the Winter.

$$
\text { Crotophaga Ani.-Lim. }
$$

\section{Ani.}

The Ani is a southern bird. I shot one specimen in the month of September, in the meadows 
below the built-up part of the City of Philadelphia. It was flying in company with a flock of rusty Gracle; the specimen is now in the Academy of Natural Sciences.

\section{Coccygus Americanus.-Bonap.}

\section{Yellow-billed Cuckoo.}

This bird is very plenty in some parts of the country I have found it more abundant in New Jersey and Pennsylvania than in any other States. I have met with it as far west as Iowa, but it is rare in that section; it breeds in lowa and the above States.

\section{Coccygus Erythrophthalmus.-Bp.}

\section{Black-billed Cuckoo.}

The Black-billed Cuckoo is very common in Iowa and all the Eastern States. It breeds in all of them; the nest is very slightly made of moss and sticks, and it does not look strong enough to hold the bird. It is noted for sucking and destroying other birds eggs. I have never found more than two eggs in one nest.

\section{Campephilus Principalis.-Gray.}

\section{Ivory-billed Woodpecker.}

I have never found but one specimen of this bird, as it is very shy and hard to approach. I found this in South Carolina. It is very plenty in Texas, where it breeds. 


$$
\begin{gathered}
\text { I8 } \\
\text { Picus Tillosus.-Linn. }
\end{gathered}
$$

\section{Hairy Woodpecker:}

The Hairy Woodpecker is very abundant in most of the Eastern States. It breeds in hollow trees, and is a resident all Winter in Iowa and west of Minnesota.

\section{Picus Pubescens.-Limn.}

\section{Downy Woodpecker.}

This bird is very common in all the States, and breeds in hollow trees west of Minnesota. Eggs four to five.

$$
\text { Picus Borealis.-I ieill. }
$$

\section{Red-Cockaded Woodpecker.}

This bird was more plenty before the large timber was cut in the State of Pennsylvania. It is found very abundant in the South. I have never found it in the West, but I have found it plenty in Florida.

Conturus Flaviventris - Sa'.

\section{Yellow-bellied Woodpecker.}

The Yellow-bellied Woodpecker is to be found in most all parts of the country, in the heavy timber, and generally breeds in holes in the trees. It is quite plentiful, remaining in the winter. Four eggs.

$$
\text { Hylotomus Pilcatus.-Baird. }
$$

\section{Black Woodpecker.}

This bird is not very abundant in the Eastern and Middle States, but is very plenty in the 
South. I have shot it in Delaware, New Jersey and Pennsylvania, and have seen it in New York State. I do not consider it rare. I obtained several specimens in the Winter of 1875 , and found it in the month of June in Iowa.

\section{Centurus Carolinus.-Bonap.}

\section{Red-bellied Woodpecker.}

This bird is not very common in the Middle States. It is found in the Spring and Fall. I have found it very abundant in Florida, and have found it breeding in Iowa and Minnesota. Like the rest of its family, it builds its nest in hollow trees. Eggs four in number; white-the same color as those of the other woodpeckers.

\section{Melanerpes Erythrocephalus.-Sa'.}

\section{Red-headed Woodpecker.}

The Red-headed Woodpecker is very common in all parts of the heavy timber country. It is also very abundant in Iowa and farther west, where it breeds, but goes south in the Winter. Eggs four or five; nests in hollow trees.

\section{Colaptus Auratus.-Swainson.}

\section{Yellow-shafted Flicker.}

This is the most common woodpecker of all, and is found in all parts of the United States and the British settlements. Nests in holes in trees, and in houses and barns. 


\section{Trochilus Colubris.-Linn.}

\section{Humming Bird.}

This beautiful little warbler travels all over the States. I have found it from Maine to Florida, and from the Atlantic Ocean to Iowa, where it is very abundant. This is owing to the vast quantity of wild flowers that grow upon the prairies. I have found it breeding in Iowa, and also in the Eastern States. Its nest is built mostly on the branch of an oak tree, and resembles a bunch of moss. Eggs white, and two in number.

\section{Chaetusa Pelasgic.-Steph.}

\section{Chimney Swallow.}

This bird is very abundant from May until September, in the Eastern States, where it breeds in the chimneys that are used in that section. I have found it a very rare bird in the West. I have found it as far west as Iowa, breeding in hollow trees. Eggs white, and as many as six in one nest.

Antrostomus Vociferus.-Bonap.

\section{Whip-poor-Will.}

The whip-poor-will is distributed throughout the country, as far west as Minnesota, where it breeds, laying two eggs upon the bare ground.

Chordeiles Popetue.-Baird.

\section{Night Hawk.}

I have found this bird very abundant during the month of August, in the mountains of Penn- 
sylvania, towards dark, feeding on mosquitoes. It is very plenty in lowa, where it breeds on the ploughed ground. It lays two eggs. I have also found it breeding on the copper roof of a store on Third street, below Race. The roof being slanting, the eggs were layed close by the chimney, a piece of mortar that had fallen from the chimney preventing them from rolling off.

\section{Chordeiles Henryi-Casssin.}

\section{Western Night Hawk.}

The Western Night Hawk is much the same as the above hawk-the only difference being in the size, which is rather smaller. Its habits are much the same. Eggs the same color, but smaller.

\section{Ceryle Alcyon-Boie.}

\section{Belted King-fisher.}

The Belted King-fisher arrives with us early in the Spring, and is found along the rivers and small creeks in search of small fish. It arrives about the month of April, in Iowa, and is very plenty. It builds its nest mostly in holes made in the river banks, but I have found its nest in hollow trees.

Milvulus Forficatus.-Sw.

\section{Scissor-tail.}

This bird is looked upon as a very singular one on account of the length of its tail. It is found in Kansas in the month of July, where it 
breeds. Eggs generally four, and they resemble those of the Tyzammes Carolinensis.

\section{Tyrannus Carolinensis.-Baird.}

\section{King Bird; Bee Bird.}

This is very abundant all over the United States, and very plenty west of the Mississippi. River. It lays from four to five eggs. Its nest $s$ generally lined with wool, and is built on low trees. I have also found its nest on low fences.

\section{Tyrammes Dominicensis.-Rich.}

\section{Gray King Bird.}

This bird is found in the interior of Florida. I procured a specimen at Key West.

$$
\text { Myiarchus Crimitus.-Cab. }
$$

\section{Great-crested Flycatcher.}

This bird much resembles the Gray King Bird, and is found in the South. It reaches us in April, and is very common here. I have never found it in the Western States. It builds its nest in low trees and stumps, and also in holes in fences. Eggs four.

Sayornis Fuscus.-Baird.

\section{Pewee.}

This is one of the earliest visitors in the Spring, arriving as early as March, and is very abundant in all parts of the United States. It breeds as early as April, and builds its nest in deserted 
fish cabins, stables, and under bridges. I have found it very plenty in Iowa and farther west.

Contopus Virens.-Cab.

\section{Wood Pewee.}

I have found this bird distributed in most of the localities that I have visited. It is very plenty, and builds its nest on the limbs of trees. The nest resembles a bunch of moss, and is much like the nest of a humming bird. Eggs four in number.

\section{Empidonax Traillii.-Baird.}

\section{Traill's Flycatcher.}

I have found it from the Atlantic to Iowa, but not very plenty. 'It is not a rare bird. It breeds on trees. Eggs, four in number.

Empidonax Minimus.-Baird.

\section{Least Flycatcher.}

This bird is very common all over the United States, I find it very plenty in Iowa, where it breeds in great numbers. Eggs four and five.

$$
\text { Empidonax Acadicus.-Baird. }
$$

\section{Green-crested Flycatcher.}

This bird is very common from New Jersey to Iowa. I have found it in Georgia and South Carolina. Breeds as far west as Minnesota. Eggs four in number. 
Empidonax Flaviventris.-Baird.

\section{Yellow-bellied Flycatcher.}

I have shot this bird in Pennsylvania, New Jersey and Iowa. It is not common. It breeds in lowa. Four eggs.

Contopus Borealis.-Baird.

\section{Olive-sided Flycatcher.}

This bird is very rare. I have found it in Philadelphia in Fairmount Park, and also in New Jersey. It breeds in pine trees. Eggs four. I have never found it West.

\section{Turdus Mustelinus. $-G m$.}

\section{Wood Thrush.}

It is very common from the Atlantic west to Minnesota, and breeds in Iowa. Eggs four in number. Nests on trees and low bushes.

\section{Turdus Pallasi.-Cab.}

\section{Hermit Thrush.}

It arrives early in the month of May, and breeds as far west as Minnesota. Eggs four in number. It is very common. It remains as late as November.

\section{Turdus Fuscescens.-Stephens.}

Wilson's Thrush.

It is very common all over the Eastern and Middle States, but rather rare in the West. I have found it breeding in New Brunswick. Eggs four in number. 


\section{Turdus Swainsonii.-Cab.}

\section{Olive-backed Thrush.}

It is not very common. It is found as far south as Virginia, and as far west as Iowa. Eggs four in number.

\section{Turdus Alicice.-Baird.}

\section{Gray-cheeked Thrush.}

It breeds in New Jersey and as far west as Iowa. It arrives in the West about the 2oth of July, and breeds the last of June. Eggs four in number.

Turitus Migratorius.-Linn.

\section{Robin.}

The Robin is very common all over the United States. It breeds in abundance in the Western States. Eggs four in number. It arrives in the West about the Ioth of May, and leaves in September.

\section{Sialia Sialis.-Baird.}

\section{Blue Bird.}

The Blue Bird is one of the earliest visitors of Spring in the Eastern States. It makes it appearance in the West about the 2oth of July, and leaves in September. It is very common in the East, but rare in the West. In mild winters it remains with us in Pennsylvania. I have known it to commence breeding as early as Marc.'.2. 


\section{Regulus Calendula.-Licht.}

\section{Ruby-crowned Wren.}

This bird is distributed all over the country. It arrives early in May in Iowa, and returns in September. It remains during the winter among the cedars along the seashore of New Jersey. I have found it in company with the Goldencrested Wren and Black-capped Tit.

$$
\text { Regulus Satrapa.-Licht. }
$$

\section{Golden-crested Wren.}

This bird remains with us during the winter, and keeps in the thick cedars in New Jersey. It is found in Iowa early in May, but does not breed there. I have found the eggs above Minnesota, in the British settlements.

\section{Anthris Ludoricianus.-Licht.}

\section{Tit-lark.}

This bird is very abundant in Spring and Fall, and mostly frequents the ploughed ground on old fields. I have found it very plenty in Virginia and in Iowa.

\section{Mniotilta Varia-I icill.}

\section{Black and White Creeper.}

I have met with this bird as far south as Florida, and west to Minnesota, where it breeds. I have found it breeding in New Jersey. Its nest is made in holes of trees. Eggs five in number. 
Parula Americana.-Bonap.

\section{Blue Yellow-back.}

It is very abundant from Georgia to Maine. I have not found it as plenty in the West. I found it breeding in New Jersey. Its nest is made of moss. Eggs four or five in number.

\section{Geothlypis Trichas.-Cab.}

Maryland Yellow-throat.

It is very abundant in the Spring in all the States, and breeds from the Atlantic to the Mississippi. Eggs four in number; and often a cow-bird egg.

Geothlypis Philadelphia.-Baird.

\section{Mourning Warbler.}

This bird is considered rare among most collectors. I have found it from Delaware to. New York, and from the Atlantic to Iowa, but have never found it breeding. Its habits are very much the same as the Geothlypis Trichas.

Geothlypis Mac gilliwayi-Baird.

\section{Macgillivray's Warbler.}

I never found this bird until I874, and then I shot three specimens in one day in the State of Iowa. It resembles the Mourning Warbler in appearance very much, and its habits are very near the same. It is found in Iowa. The specimen is in my collection. 


\section{Oporornis Agilis.-Baird.}

\section{Connecticut Warbler.}

This bird very much resembles Macgillivray's Warbler. I have often met it while hunting partridges in the wheat stubble, and have killed as many as seven in one day. They keep along the fences, and are easily observed by those who are fond of Ornithology and are acquainted with the bird.

\section{Oporomis Fonmoszes.-Baird.}

\section{Kentucky Warbler.}

It is not very plenty. I have met with it in the mountains of Pennsylvania, and also in New Jersey. I found it swampy woods. It is considered rare.

\section{Ictoric liridis.-Bonap.}

\section{Yellow-breasted Chat.}

It is very abundant in the Southern States, and as far north as New Jersey and Pennsylvania. It breeds in June. Eggs four in number. I have never met with it in the W'estern States.

\section{Helmitherus Tormizonus.-Bonap.}

\section{Worm-eating Warbler.}

It is very rare. I have met with it on the banks of the Schuylkill River, but since the improvements in that section I find it scarce; the timber being cut, they seek some other locality. 


\section{Helminthophaga Pinus.-Baird.}

\section{Blue-winged Yellow Warbler.}

It is rather rare, but I have found it in Pennsylvania and Iowa. It arrives in May in company with most of the warbler tribe, and breeds on trees. Eggs four in number.

\section{Helminthophaga Chry'soptera.-B.}

\section{Golden-winged Warbler.}

I have found this bird very abundant in Iowa, where it breeds, but have never found the nest. I have shot it in Pennsylvania and New Jersey. It is not considered rare.

\section{Hchminthophaga Ruficapilla.--Bd.}

Nashville: Warbler.

It is very abundant as far as Minnesota, and I have'shot it in New Jersey. I have found it to frequent the tops of high trees. It is not considered rare.

\section{Hclminthophaga' Celata.-Baird.}

\section{Orange-crowned Warbler.}

It is very abundant in Iowa. I have not often met with it in the Eastern States. I found one in the month of December, in New Jersey, when there was a deep snow on the ground, which must have been a straggler. 


\section{Hclminthophaga Percgrina.-Cab.}

\section{Tennessee Warbler.}

I have found this bird very abundant in Iowa, in company with the other species of the warbler tribe, but I have never met with it in the East.

Seiumes Aurocapillus.-Sic.

\section{Golden-crowned Thrush.}

It is very common in all parts of the country. I have found it very plenty in Iowa and Minnesota, where it breeds, its nest being on the ground, and containing from four to five eggs. It also breeds in New Jersey and Pennsylvania.

Seiumus Noveboracensis.-Nutt.

\section{Water Thrush.}

I have found. it from the Atlantic to the Mississippi, but never found it breeding very abundant in Iowa and Minnesota.

Seiurus Ludovicianus.-Bonap.

\section{Large-billed Water Thrush.}

This bird resembles Noicboracensis, with the exception of the bill, which is larger. I have only met with it in New Jersey and Iowa.

\section{Dendroica Virens.-Baird.}

\section{Black-throated Green Warbler.}

It is very abundant in Spring and Fall, from Georgia to Maine, and from the Atlantic to Iowa, where it breeds. Nests in trees and bushes. Eggs four to five in number. 
Dendroica Canadensis.-Baird.

\section{Black-throated B:ue Warbler.}

It is very common in the Spring, in Maine, and also in Iowa, where it breeds. I have never found the nest, except in Iowa. Eggs four in number.

\section{Dendroica Coronat.x.-Gray.}

\section{Yellow-rump Warbler.}

It is very common throughout the country. It breeds in New Jersey and as far west as lowa. Eggs four to five in number.

\section{Dendroica Blackburnia.-Baird.}

\section{Blackburnian Warbler.}

It is very common in some seasons. I liave found it very plenty in New Jersey, and very scarce in Iowa. Eggs four to five in number.

\section{Dindrica Castanea.-Baird.}

\section{Bay-breasted Warbler.}

I have seen this bird very abundant some seasons, and at other times could not procure one. It is very rare in Iowa.

\section{Dindroica Pinus.-Baird.}

\section{Pine-creeping Warbler.}

It is very abundant in New Jersey, and is found feeding on pine trees in the Spring. I have found it very common in Virginia, and also in Iowa in the Spring of 1875 . 
Dendroica Pennsylianica.-Baird.

Chestnut-sided Warbler.

It is very common all over the country. I found it breeding in the mountains of New York, and in the State of Minnesota. Eggs four to five in number.

\section{Dentroica. Carulea.-Baird.}

\section{Blue Warbler.}

It is very rare in the Eastern States. I have found it very abundant along the Mississippi River, in Iowa.

\section{Dendroica Striata.-Baird.}

\section{Black-poll Warbler.}

It is very common in all the States, and one of the latest to arrive in Spring. It breeds in Maine and Iowa.

\section{Dendroica Aestiza.-Baird.}

\section{Yellow Warbler.}

This is the most common of all the warbler tribe, and is distributed all over the country. I have found it breeding in gardens near houses, and it appeared to be very tame. I have met with it on the prairies where there were no dwellings within ten miles. Its nest is made of hemp, and generally lined with wool and twine. Eggs four to five in number. 
Dendroica Maculosa.-Baird.

\section{Black and Yellow Warbler.}

It is very abundant some seasons-remains but a short time, and then leaves for the mountains where it breeds. It is rare in Iowa.

\section{Dendroica Tigrini-Baird.}

\section{Cape May Warbler.}

It is rather rare. I have found it in New Jersey and Pennsylvania, and as far west as Minnesota and Iowa.

\section{Dendroica Palmarum.-Baird.}

\section{Yellow Red Poll.}

This is one of the first visitors of the warblers in Spring, and is very common all over the country. I have found it breeding in Maine and lowa. Nests on cedar bushes. Eggs from four to six.

\section{Dendroica Superciliosa.-Baird.}

Yellow-throated Warbler.

I have found this bird very abundant in the South, in the neighborhood of Charleston, South Carolina, where it breeds. I have never found its nest.

\section{Dendroica Discolor-Baird.}

\section{Prairie Warbler.}

I found this little bird very ahun lant at Indian Key, in Florida, its plumage being in a very bad condition. I also found it in New Jersey, the 
nest being on small fern bushes. Eggs five in number.

$$
\text { Myiodioctes Mitratus.-Aud. }
$$

\section{Hooded Warbler.}

It is very rare. I have found it Freeding in the mountains of Pennsylvania and New York, and have also found it in New Jersey. Eggs five in number.

\section{Myiodioctes Pusillus.-Bonap.}

\section{Green Black-cap Flycatcher.}

It is not very common here, but I found it in New Jersey and Pennsylvania, and as far west as Minnesota, where it breeds.

\section{Myiodioctes Canadensis.-Aud.}

\section{Canada Flycatcher.}

It is very common, and breeds from the Atlantic west to lowa. It also breeds in the State of Maine.

$$
\text { Setophaga Rutcilla.-Szo. }
$$

\section{Redstart.}

It is very common in all parts of the country. I have found it breeding from New Jersey to Maine, and west to Minnesota. Eggs from four to five.

$$
\text { Pyranga Rubra.-Vieill. }
$$

\section{Scarlet Tanager.}

It is very common in Spring, from Florida to New York, and west to Iowa. It keeps mostly 
in heavy oak timber, and I often found it on new p'oughed ground or fields, searching for worms. It breeds in Iuwa. ivests on oak trees. Eggs four in number.

$$
\text { Pyranga Aestiva.-Vieill. }
$$

\section{Summer Red Bird.}

I found this bird very plenty in Virginia about the Ist of May. I also found it breeding in New Jersey. Nesis on low pine trees. Eygys four in number, and much the same as $P$. Astera.

$$
\text { Hirundo Horreoram.-Barton. }
$$

\section{Earn Swallow.}

It is generally distributed over the country, but is not very plenty in Iowa or Minnesota.

\section{Cliff Swallow.}

$$
\text { Hirundo Lunifrons. - Say. }
$$

It is very abundant in Iowa and Minnesota, also in the mountains of New York, and as far south as Pennsylvania. I have found it breeding on Leagrue Island.

$$
\text { Hirundo Bibolor. - Vieill. }
$$

\section{White-bellied Swallow.}

It is very common all over the country and breeds in hollow trees. Eggs from four to six.

$$
\text { Cotyle Riparia.-Boie. }
$$

\section{Bank Swallow.}

It is very common from Maryland to Pennsylvania and Canada, and west as far as Minnesota. 
Cotyle Serripennis.-Bonap.

\section{Rough-winged Swallow.}

I have found this bird from Delaware to New York, and from the Atlantic to Minnesota. I found it breeding in Iowa in company with Cotyle Riparia. Eggs six in number.

Progne Purpurea.-Boie.

\section{Purple Martin.}

This bird was to me some years ago very abundant about Philadelphia, but in the last few years I found it very scarce. I found it very abundant in lowa and farther west, brecding in hollow trees and stumps.

Ampelis Garrulus.-Linn.

\section{Wax Wing.}

I have found this bird very plenty in Iowa, in the Winter, and have known it to be shot in Maine. I have seen a specimen that was killed in West Philadelphia in the Winter of $184 \mathrm{I}$. It was feeding with some cedar birds on the berries of the cedar trees. It is considered very rare. Most of the rare birds have a locality where they may be found very plenty.

\section{Ampelis Cedrorum.-Baird.}

\section{Cedar Bird.}

The Cedar Bird is found over the country from New Jersey to Minnesota, and breeds in Iowa. 
I have found it very plenty in Maine, and as far south as North Carolina, where it remains in Winter.

\section{Collyrio Borealis.-Baird.}

\section{Great Northern Shrike.}

This bird is not often met with in Pennsylvania, except in the Winter, and then it feeds on snow birds and sparrows. It breeds in Minnesota. Eggs four in number. It is not common.

\section{Collyrio Ludoicianus. - Baird.}

\section{Loggerhead Shrike.}

I found it very common in Georgia, where it breeds, and I have found it as far north as Pennsylvania.

\section{Collyrio Excubitoroides.-Baird.}

\section{White-rumped Shrike.}

I have found this bird for many seasons, breeding in Iowa, near Clear Lake. It builds its nest on low oak bushes. Eggs four in number. It is very shy when you approach its nest, and hard to get a shot at.

\section{Vireo Olizaceus.-I'ieill.}

\section{Red-eyed Flycatcher.}

It is very common all over the country; and arrives in Iowa about the Ioth of May. Eggs four in number. 


$$
\begin{aligned}
& 3^{8} \\
& \text { Iireo Altiloquus.-Gray. }
\end{aligned}
$$

\section{Whip Tom Kelly.}

I have found but one specimen of this bird, and that I found at Key West, Florida, while I was in company with Dr. Herman.

$$
\text { I irco Philadelphicus.-Cassin. }
$$

\section{Philadelphia Vireo.}

I found this bird very abundant about Davenport, lowa, where it breeds. Eggs four in number. I have also found it in Minnesota, but have never met with in the Eastern States.

$$
\text { Irreo Gilius.-Bonap. }
$$

\section{Warbling Flycatcher.}

It is very common from the Atlantic to Minnesota. It breeds in lowa and is very plenty. Eggs four in number.

\section{Vireo Naveboracensis.-Bonap.}

\section{White-eyed Vireo.}

It is very common south to Florida, and north to New York, but I have never found it farther west than the mountains of Pennsylvania.

\section{Irreo Solitarius.-Vieill.}

\section{Blue-headed Flycatcher.}

It rather rare. I have never procured more than four in a season. I have found it breeding in Iowa and also in Pennsylvania. 


\section{I ireo Flazifrons. - Vieill.}

\section{Yellow-throated Flycatcher.}

It is very abundant early in the Spring, in Iowa and Minnesota, where it breeds. It arrives very early in May, in New Jersey and Pennsylvania.

$$
\text { Mimus Polyglottus.-Boie. }
$$

\section{Mocking Bird.}

I have found this bird very plenty in Virginia, and have shot it in New Jersey, Delaware and lowa. I found a nest which had four eggs in it.

$$
\text { Mimus Carolinensus.-Gray. }
$$

\section{Cat Bird.}

This bird is very common all over the country, and arrives the Ist of May in Iowa and Minnesota.

$$
\text { Harporahynchus Rufus.Cab. }
$$

\section{Brown Thrush.}

This is one of the early visitors all over the country, and one of the first to leave. I have found it very abundant in all parts that I have hunted.

\section{Thryothorus Ludovicianus.-Bonap.}

\section{Great Carolina Wren.}

I found this bird plenty about Charleston, South Carolina, and have killed it in Pennsylvania and New fersey. I have found it breeding at Red Bank, New Jersey. 
Thryothomus Bewickii.-Bonap.

\section{Bewick's Wren.}

It is rare in the Middle States. I never shot but two specimens; one in New Jersey and the other in Pennsylvania.

$$
\text { Cistothorus Palustris. - Cab. }
$$

\section{Long-billed Marsh Wren.}

This is a very common bird along the banks of the Delaware River, but I have never found it on the seashore. I found it very plenty as far west as Minnesota.

\section{Cistothorus Stellaris.-Cab.}

\section{Short-billed Marsh Wren.}

I found this bird very rare. I killed one in New Jersey, and found the nest with five eggs in it. It is more plenty in Iowa, but very hard to obtain, as it runs among the grass and along the sloughs and wet places. The nest found in New Jersey was built on a low bush in the salt meadows. This bird in the West, builds on the high reeds and cat-tails along the creeks and sloughs.

Troglodytes Aedon._-Vieill.

\section{House Wren.}

It is very common all over the United States. Troglodytes Parkmanni-Aud.

\section{Parkman's Wren.}

I have found this very plenty in Iowa, breeding in old stumps and holes in trees, and it resembles 
the Housa Wren so much that it is hard to decide whether it is the same bird. It breeds in the woods, and the eggs are of a lighter color than the House Wren.

$$
\text { Truglodytes Hymalis-I icill. }
$$

\section{Winter Wren.}

It is not very common. It is found from Pennsylvania to Iowa, and keeps in wood piles and rocky places. It breeds in Minnesota, north of St. Paul. One nest of this bird was found along the Schuyllkill River. The nest resembles that of the European one, both in structure and size.

\section{American Creeper.}

Certhia Amiriana.-Bonap.

I have found this bird as far west as Iowa, and also in Maine. It is not common. Those found in Maine are much larger than those in Pennsylvania, and in the West the bill is much longer and more curved.

\section{Sitta Carolinensis.-Gmelin.}

\section{White-bellied Nuthatch.}

It is very common throughout the country. I found it breeding in Iowa. Nests in holes in trees.

\section{Sitta Canadensis. - Linn.}

\section{Red-bellied Nuthatch.}

I have found this bird very plenty in Iowa, and also found it breeding there in holes and trees. 
Its eggs are much the same as the Carolinensis. and smaller. It is very plenty in Pennsylvania. in Autumn.

\section{Sitta Pusilla-Lattiam.}

\section{Brown-headed Nuthatch.}

I found this bird very common in North Carolina. I also found it breeding in holes in trees, and caught the bird on its nest. Eggs five in number, and much the same as those of the Canadensis.

\section{Polioptila Carulea.-Silat.}

\section{Blue-gray Gnatcatcher.}

In some seasons it is very plenty along the Schuylkill River, keeping in the high trees. $I$ 'have found it in Virginia. It is not rare.

\section{Lophophanes Bicolor.-Bonap.}

\section{Tufted Titmouse.}

It is not very plenty. I have found it from Virginia to the mountains of Pennsylvania; and found it breeding in heavy timber in New Jersey. Eggs five in number. Nests, in holes in trees.

$$
\text { Parus Atricapillus.-Linn. }
$$

\section{Black-cap Titmouse.}

This bird is distributed all over the country. It breeds from South Carolina to Maine, and from New Jersey to Iowa. It is common. 


\section{3 \\ Panus Carolinensis.-Aud.}

\section{Carolina Titmouse.}

I have never found this bird north of Georgia. It is very scarce.

\section{Eremophila Cornuta.-Boie.}

\section{Sky Lark.}

It is very abundant along the shores of the Delaware, in the Winter, as far south as Virginia. I found it breeding in Iowa, and also found young birds in the early part of April. The inhabitants say they lay early in March, when the ground is covered with snow. I have found the young when the ground was covered with three inches of snow. I have also found the nest in. June. Eggs four in number.

\section{Pinicola Canadensis.-Cab.}

\section{Pine Grosbeak.}

It is seldom found in Pennsylvania, except in very cold winters. It is very plenty in Iowa and Maine.

Carpodacus Purpureus.-Gray.

\section{Purple Finch.}

It is very abundant in the Winter in New Jersey and Pennsylvania, and also plenty in Iowa where it breeds in the Summer. I have found it in Maine in the month of June. 
Chrysomitris Tristis.-Bonap.

\section{Yellow Bird.}

This bird is well distributed orer the States. I have found it from South Carolina to Maine, and from New Jersey to Minnesota. It breeds in Maine, Iowa and Minnesota, where I found its nest. Egrgs four in number.

Chrysomitris Pinus.-Bonap.

\section{Pine Finch.}

It is not often found in Pennsylvania, except in the Winter. I have found it very plenty in Iowa in the month of September, feeding on lettuce seed in company with the Chrysomitris Tristis.

\section{Curitrostra Americana.-Wils.}

\section{Red Crossbill.}

I have found this bird in the Winter, from Virginia to New York. I met with it in June in New Jersey, near Red Bank, and in June the next year in Maine. I sound it in Autumn in Iowa. It is very plenty.

$$
\text { Cunirustra Lencoptera.-IVils. }
$$

\section{White-winged Crossbill.}

I found this bird very abundant in the Winter of 1845 , in New Jersey. I have never found it but once in that locality. I found it in Maryland in the month of March, in 186I, and have not met with it since. It is considered rare in this State. 
Aegiothus Linaria.-Cab.

\section{Lesser Red Poll.}

I found this bird very abundant in some -winters in Penusylvania. I also found it very plenty in Iowa, where it remains a few weeks, and then leaves for warmer quarters.

Plectrophanes.-Nivalis.

\section{Snow Bunting.}

It is very abundant in some winters along the Delaware River, and along the roads when the snow is on the ground. I have killed a great many of these birds on the ground where the Eastern Penitentiary and the Girard College now stands. It is very plenty in Iowa.

\section{Plectrophanes Lapponicus.-Selby.}

\section{Lapland Longspur.}

This bird was considered rare some years ago. I can say that it was as plenty in lowa the last of April, as the Snow Bunting. I have found it in flocks of thousanas, feeding on the wheat fields. The farmers call it the wheat bird, and would like some one to kill them all, as they devour an immense amount of whent after it is sown, and do not leave until the crop begins to sprout.

$$
\text { Passerculus Savanna.-Bonap. }
$$

\section{Savannah Sparrow.}

It is very abundant in Spring, and is found in the meadows south of the City of Philadelphia. It is also found in New Jersey and west to lowa. 


\section{Pooecetes Gramineus.-Baird.}

Grass Finch.

It is very common in Spring in New Jerseyand Penusylvania, and some few remain during a mild Winter. It is not often found in Iowa.

\section{Cotuniculus Passerinus.-Bonap.}

\section{Yellow-winged Sparrow.}

It is very plenty, and is one of the early Spring visitors. It is very abundant upon the prairies of the West, where it breeds. Eggs four in number.

\section{-Ammodronnus Caudacutus.-Swe.}

\section{Sharp-tailed Finch.}

It is very abundant along the seashore from New York to Georgia. I have found it breeding in great numbers at Atlantic City.

Ammodromus Maritimus.-Sw.

Sea-side Finch.

I found it along the shores breeding on the salt meaclows. Its nest is built on low bushes. I found it breeding in company with $A$. Caudacutus.

\section{Zonotrichia Leucophrys.-Swe.}

\section{White-crowned Sparrow.}

It is found in the mountains of Pennsylvania, where it breeds. I found one specimen in Camden, N. J. Rare. 


\section{Zonotrichia Gambelii.Gambel.}

Gambel's Finch.

In the month of May, 1875 , I shot two specimens in Iowa, the first of this bird I ever met with. Rare.

\section{Zonotrichia Cormata.-Baird.}

\section{Golden-crowned Sparrow.}

I shot one of these birds in September of i 872 , in a garden in Lake Mills, Winnebago Co.. Iowa. Rare.

\section{Zonotrichia Querula-Gamb.}

\section{Harris's Finch.}

I found this bird very abundant in Iowa. It arrives about the Ist of May, and remains until June, then returns again in September. I have never found its nest.

\section{Zonotrichia Albicollis.-Bonap.}

\section{White-throated Sparrow.}

This bird remains with us in mild winters. I have found it in very cold weather, with snow on the ground, in New Jersey, feeding about Pennsylvania in company with the Song Sparrow, Grass Finch and Tree Sparrow. I found it breeding in Maine and Iowa. Eggs four in number. 


\section{Funco Hyemalis.-Sclat.}

\section{Black Snow Bird.}

It is very abundant in Winter, and arrives in October. Breeds in Maine and Minnesota, and arrives in Iowa in the month of May.

Spisellar Monticoli.-Baird.

\section{Tree Sparrow.}

This bird is very common in Winter, and leaves early in the Spring. I have found it in the month of May in Minresota, but cannot say whether it breeds there or not.

$$
\text { Spizella Pusilla.-Bonap. }
$$

\section{Field Sparrow.}

It is very common in Spring and is one of the early visitors. I have never met with it west of the Alleghany mountains.

\section{Spizella Socialis.-Bonap.}

\section{Chipping Sparrow.}

This is one of the early visitors in Spring, and remains very late in Autumn. I found it in May in Iowa. It is not very plenty, and not much in company with other birds.

$$
\text { Spizella Pallida.-Bonap. }
$$

\section{Clay-colored Bunting.}

I found this bird in Winnebago Co., Iowa, in company with $S$. Socialis. I found it breeding in Minnesota, Eggs four in number, and resembling those of the s,isilla Pusill.t. 


\section{Melospiza Melodia.-Baird.}

\section{Song Sparrow.}

It is very common all over the country. Leaves Iowa in October.

\section{Melospiza Lincolnii.-Baird.}

\section{Lincoln's Finch.}

I found this bird very plenty in Iowa, where in breeds. It is more numerous than any of its family in that section. Very common.

\section{Melospiza Palustris.-Baird.}

\section{Swamp Sparrow.}

It is very common from the Atlantic to Minnesota, where it breeds.

Passerella Iliaca.-Sw.

\section{Fox-colored Sparrow.}

This is a common bird with us in Spring and Autumn. I have met with but few in the West.

Calamospiza Bicalor.-Bonap.

\section{Lark Bunting.}

I shot two specimens in the Spring of 1875 , in Winnebago Co., Iowa. I have seen them frequently when riding along the road. In other counties it is very plenty, and always in pairs.

Euspiza Americana.-Bonap.

\section{Black-throated Bunting.}

Many years ago this was a very common bird about Philadelphia, but for some seasons it has 
become rare. I found it very abundant in Iowa, breeding on the prairies.

\section{Guiraca Ludoviciana.-Sw.}

\section{Rose-breasted Grosbeak.}

This beautiful songster is much sought after by collectors about Philadelphia, and is considered rare. I have found it very common in Iowa and Minnesota. It arrives the Ist of May.

\section{Guiraca Cerulea.-Sus.}

\section{Blue Grosbeak.}

It is very rare. I have never found it except in Delaware, and there it was not plenty.

\section{Cyanospiza Cinis.-Baird.}

\section{Painted Bunting.}

I found this bird very plenty in Florida, where it breeds, but could not obtain a nest with eggs.

\section{Indigo Bird.}

\section{Cyanospizo Cyanea.-Baird.}

It is very plenty from Delaware to New York, and from New Jersey to Iowa.

\section{Cardinalis Virginianus.-Bonap.}

\section{Red Bird.}

It is very abundant from South Carolina to Pennsylvania, and remains with us in the Winter. It breeds in June. I have never met with it in the West. It is said to be found in Minnesota, yet I have never found it. 


\section{Pipilo Erythrophthalmus.-Vieill.}

\section{Ground Robin; Towhee.}

It is very common all over the country, and breeds in lowa in great numbers.

\section{Dolichonyx Oryzironus.-Siu.}

\section{Boblink; Reed Bird.}

It is very common in the South where it winters, and makes it appearance on the Ist of May, in Pennsylvania, and also in Iowa, where it breeds in great numbers all over the prairies. It leaves Iowa about the ioth of August, in large flocks. It makes its nest on the ground, and is very shy when any one approaches it. I found one nest to contain six eggs, and also a cow bird's.

\section{Molathrus Pecoris.-Szo.}

\section{Cow Bird.}

This is called by most of the collectors, the lazy bird, because it lays its eggs in other birds' nests. I have found it in the nest of the Maryland Yellow-throat, Blue Bird, Black-throated Green Warbler, Yellow Warbler, Redstart and Boblink. It is very common in the country. I found it very abundant in Iowa and Maine.

\section{-Ageluius Phoniceus.-Vieill.}

\section{Red-winged Black Bird.}

It is very common in all the States. It arrives in Pennsylvania in the month of March, and makes its appearance in lowa in the month 
of April. It remains in the West as late as October.

Xanthocephalus Icterocephal's.

\section{Yellow-headed Blackbird.}

It is very abundant in Iowa, Minnesota and $W$ isconsin. Breeds along the creeks and marshes, and on the reed and cat-tail flags. Eggs four to five.

Sturnella Magna.-Sw.

\section{Meadow Lark.}

It is very common from New Jersey to Minnesota. It builds its nest on the ground. Eggs four to five.

Sturnella Neglecta.-Aud.

Western Lark.

I shot several specimens of this bird in the northern part of Iowa, and found them breeding. Nests on the ground. Eggs four in number. Not common.

\section{Icterus Spurius.-Bonap.}

\section{Orchard Oriole.}

Breeds in great numbers in Iowa. It is not as plenty in New Jersey and Pennsylvania as it was some years ago.

Icterus Baltimore.-Daudin.

\section{Baltimore Oriole.}

This beautiful bird was some years ago very abundant in New Jersey and Pennsylvania, but 
for some seasons it has become scarce. I have found it very plenty in the Western States, breeding in Iowa, Minnesota and Wisconsin in large numbers.

Scolecophagus Fermgincus.-Sw.

\section{Rusty Blackbird.}

In March this bird makes its appearance in Pennsylvania, and moves westward. I found it in the month of April in lowa, the snow being still over the country. I found it breeding in May. Eggs four in number, and nest built on low hazel bushes, similar to that of the Red Wing, which is often found in company with it.

\section{Quiscalus Major-Vieill.}

\section{Boat-tailed Grakle.}

I shot this bird in Florida. I found it breeding, and its eggs resemble those of $Q$. T'ersicolor, only' larger. Nests on low bushes. Eggs four in number.

\section{Quiscalus J'ersicolor.-Vicill.}

\section{Crow Blackbird.}

It is very abundant, breeding from Maine to South Carolina, and from the Atlantic to Minnesota. It is very destructive to farmers in cornfields. I found its nest built on the ground in the West, and in New Jersey built under the nest of a fish-hawk. 
Corvus Carnivorus.-Bartram.

\section{American Raven.}

I have often met this bird on the beach from Barnegat to Cape May, and found it very shy and hard to obtain. I found it feeding upon the carcasses of ducks. I obtained a specimen from Maine, in the flesh, which was much larger than the one found in New Jersey.

\section{Corous Americanus.-Aud.}

\section{Common Crow.}

This bird is very abundant in New Jersey and Pennsylvania, and also in Delaware. I have never seen many west of Ohio. I never killed but one in Iowa, and that was much smaller than the Easteri. As a general thing, the crows vary in size, but not as much as this one.

\section{Fish Crow.}

$$
\text { Corous Ossifragus.-Wilson. }
$$

This crow makes its appearance along the Delaware in Spring, when the shad fishermen commence to haul their nets, to feed on the small fish that are left on the shore. I have found them in North Carolina. I have found them breeding in New Jersey in May. Nests on pine trees. Eggs four in number.

$$
\text { Pica Hudsonica.-Bonap. }
$$

\section{Magpie.}

I was fortunate enough to find one specimen of this bird in the Spring of 1875 , in Winnebago Co., Iowa. 


\section{Cyanura Cristata.-Sw.}

\section{Blue Jay.}

It is very abundant from the Atlantic to Minnesota. I have seen flocks of more than a hundred at a time, flying over the timber at Benson Grove, in Iowa, for several days. They breed very abundant in Iowa, and are very tame.

\section{Ectopistes Migratoria.-Sw.}

\section{Wild Pigeon.}

Very abundant in Spring and Autumn, when migrating. I have found them in immense numbers in Wisconsin, and have seen so many alight upon an oak tree that they broke the limbs off. I found it in Iowa in I 875 , breeding in Benson Grove, and also at Clear Lake, where it was more plenty.

\section{Zenaidura Carolinensis.-Bonap.}

\section{Common Dove.}

Very common in all parts of the country. Breeds very abundant in Iowa.

\section{Chamapelia Passerina.-Sw.}

\section{Ground Dove.}

This little dove is very abundant at Key $\mathrm{W}^{\top}$ est, Florida, where it breeds. I shot one specimen in the pine woods of New Jersey, which I suppose was a straggler. I have been out hunting quail in November, and on my return through a 
thick pine woods towards the ferry, this bird would fly up from the ground.

$$
\text { Meleagris Gallopavo.-Linn. }
$$

\section{Wild Turkey.}

It is found in the mountains of Pennsylvania. Very plenty in North Carolina and Virginia. I have found them in Iowa, but they are scarce and hard to obtain. I also found it very abundant in Florida.

\section{Tetrao Canadensis.-Linn.}

\section{Spruce Partridge.}

Very abundant in the thick forests of Maine, and also about Lake Superior.

\section{Pedioecetes Phasianelluts.-Baird.}

\section{Sharp-tailed Grouse.}

I found this bird in Iowa and Minnesota, where it breeds. In some seasons it is very plenty. .

$$
\text { Cupidonia Cupido-Baird. }
$$

\section{Prairie Hen.}

Very numerous in all the Western States. I met with it in New Jersey in I840.

$$
\text { Bonasa Umbellus.-Steph. }
$$

\section{Ruffed Grouse.}

Very abundant from New Jersey to Maine, and as far west as Iowa. 
Var. Bonasa Umbelloides.-Baird.

\section{Gray Mountain Grouse.}

I met with this bird in thick timber in Iowa and Minnesota. I can see but very little difference between it and Bonasa Umbcllus, except the color on the tail feathers, and size, which is smaller.

\section{Ortyx Virginanius.-Bonap.}

\section{Partridge; Quail.}

Very abundant from Florida to Pennsylvania. I found them very numerous in Wisconsin, and very few in Iowa.

\section{Grus Ancricanus.-Ord.}

\section{Whooping Crane.}

This bird I found breeding in Winnebago Co., Iowa, and was very shy and hard to approach. It flies in great numbers in Autumn, toward the South. I have seen them in Florida, build their nests in sloughs and lakes, upon musk-rat houses.

\section{Grus Canadonsis.-Tomm.}

\section{Sand-hill Crane.}

Very abundant in the West and South. I found them very plenty in Iowa, breeding in May. I found the eggs late in June, and hatched them under a hen. The young of this bird are very singular when hatched, and if not kept separate, will fight until one has killed the other. 
The old bird lays but two eggs, and when the first leaves the egg, the male takes it off and takes care of it; the female takes care of the other until they reach maturity, then they assemble together. I have found the young upon the prairies, only one at a time, and not far distant. I would then find the other, and if put together, they would fight.

\section{Demiegrettu Ludoricianu.-Baird.}

\section{Louisiana Heron.}

I met with this heron with many others, on the Keys, in Florida. I shot several, but they falling in the water, I could not procure but one specimen.

\section{Garecta Candidissima.-Bonap.}

\section{Snowy Heron.}

This bird I also found very abundant in Florida, and have found it very plenty on the Seven Mile Beach, Cape May Co,, New Jersey. I found it breeding in May in great numbers.

\section{Herodias Egretta.-Gray'.}

\section{White Heron.}

I also found this bird as far south as Florida, the Delaware, Seven Mile Beach, of New Jersey, and along the streams as far west as Iowa.

$$
\text { Ardea Herodias.-Linn. }
$$

\section{Great Blue Heron.}

Very common along the Delaware River, south to Florida, and west to lowa. Breeds on 
the beach in Cape May Co., New Jersey, in company with the Night Heron.

Florida Carulea-Baird.

\section{Blue Heron.}

This, with many other herons, is very abundant in Florida. They keep in large flocks, and feed among the mangrove bushes in the swamps. I found this bird breeding in company with $G$. Candidissima, in Cape May Co., New Jersey. Ardetta Exilis.-Grun'.

\section{Least Bittern.}

Very common along the Delaware River, and breeds in great numbers as far west as Iowa.

Botaurus Lontiginosus.- Steph.

\section{Bittern; Stake Driver.}

Very common all over the States, and breeds in great numbers in lowa. This bird has a great many names, such as Dunkey-doo, Bunkalett, Stake Driver, and in the West it is called Thunder Pumper.

$$
\text { Butorides Virescons.-Bonap. }
$$

\section{Green Heron.}

Very common on all the creeks. Breeds on the Seven-Mile Beach, New Jersey, and West to Iowa.

Nyctiardea Gardeni.-Baird.

\section{Night Heron.}

Very abundant from Florida to New York, and west to Iowa, Minnesota and Dakota. I 
found it breeding on the beach at Cape May in company with the Snowy and Blue Heron, and in Florida in company with the same, and also the Brown Pelican.

$$
\text { Ibis . Hba-Vieillot. }
$$

\section{White Ibis.}

I found this bird very numerous at Snake Key, Florida, but in very poor plumage, not being able to obtain a good specimen.

$$
\text { Ibis Ordii-Bonap. }
$$

\section{Glossy Ibis.}

This bird is often shot in September, on the marshes of the Delaware River. When shooting rail I have seen as many as four killed in a day.

$$
\text { Phoenicopterus Ruber.-Linn. }
$$

\section{Flamingo.}

Very numerous on the Keys along the Florida coast, standing in line like soldiers.

Charadrius lirginicus.-Borck.

\section{Golden Plover.}

This is a rare bird to get in full plumage. Never got but two in full plumage. They are found frequenting the marsh in Cape May coun. ty, New Jersey.

$$
\text { Aegialitis I'ocifcrus.-Cassin. }
$$

\section{Killdeer.}

Very abundant along the Jersey coast, and west to Iowa. Breeds upon the prairies. Eggs four. 


\section{Aegialitis W'ilsonns. - Cassin.}

\section{Wilson's Plover.}

Breeds in great numbers from Virginia to Long Island, along the seashore. Eggs four, laid on the sand. The eggs of this bird resemble those of the Vociferus, but are not as much pointed.

$$
\text { Aegialitis Semipalmatus.-Cab. }
$$

\section{Semipalmated Plover.}

Very abundant in May, when migrating along: the Delaware River, also along the seashore. Makes its appearance in Iowa the first of June, where it breeds. Eggs four, laid on the bare ground on the prairie, near sloughs and creeks.

\section{Piping Plover.} Acgialitis Mclodus. - Cab.

Very abundant along the seashore from Virginia to Long Island. Breeds on Seven Mile Beach and Peck's Beach, Cape May county, New Jersey. Eggs four in number, laid on bare sand.

Squatarala Helietica.-Cur.

\section{Black-bellied Plover.}

Very abundant along the seashore in Spring and Autumn. It is also abundant in Iowa, where it arrives about the Ist of May, feeding over the plowed ground.

$$
\text { Hocmatopus Palliatus.-Temm. }
$$

\section{Oyster Catcher.}

It is found along the seashore from Virginia to Barnegat, New Jersey. I found it breeding on 
Peck's Beach, New Jersey, and also found the young birds running along the beach, feeding with the parent bird. Two eggs are all I have found in a nest, which is made of sea-drift.

\section{Strepsilas Intorpres.-Illig.}

\section{Turnstone.}

Very abundant about the roth of May, along the seashore, feeding upon the eggs of the kingcrab; and arrives about the same time in Iowa, in great numbers, feeding on the craw-fish about the sloughs on the prairie.

Recuritrostra Ancricana.-Gm.

\section{American Avoset.}

I found it upon Egg Island on the Delaware river, in the month of June, also in Kansas, on the first of June, where it breeds.

\section{Himantopus Nigricollis.-Vieillot.}

\section{Black-Necked Stilt.}

I have never found but one specimen of this bird which I have been able to shoot at, but have seen others on Egg Island, in Delaware Bay, where it breeds.

\section{Phalaropus Wilsonii-Sab.}

\section{Wilson's Phalarope.}

Breeds in large numbers in Iowa. The nest is made close to the sloughs upon some drift grass or reeds. Eggs four. It makes its appearance about the 2oth of May. Breeds in June. 
Never found but two specimens in the Eastern States.

\section{Red Phalarope.}

Phalaropus Fiulicarius.-Bonap.

Found in Maine. Breeding on the Lakes. Never found but two specimens in full plumage. Very rare.

\section{Philohela Minur:-Gray.}

\section{Americann Woodcock.}

Breeds from Maryland to Maine, and from the Atlantic to Minnesota. Some seasons very plenty. Egrgs four. Nest on the ground made of leaves and grass. I have found it breeding in Delaware as early as March, when snipe shooting. This nest was on a high tussick, with water around it about eight inches deep.

\section{Gallinago II ilsonii.-Bonap.}

\section{English Snipe.}

Very abundant over the United States. Found it breeding in Maine and Iowa. Eggs four.

Hacrorhampluzs Griseus.-Leach.

\section{Red-breasted Snipe.}

Very abundant in the month of May in the meadows along the sea coast, passing through Iowa about the first of June, flying westward. Never found the egg. 
Mircrorhamphus, Scolopaceus.-La.

Greater Longbeak.

Very abundant in the Spring and Autumn along the sea-coast, feeding on salt meadows. Arrives in Iowa about the first of June in large flocks, feeding on the burnt prairies.

Tringa Canutus.-Linn.

\section{Knot.}

This bird, like the most sand-pipers, keeps along the seashore in the Spring and Autumn in great numbers. I found it in the month of May marching westward, stopping a day or two in Iowa, feeding along the slough. Very easy to approach.

Tringa Maritima.-Brannich.

\section{Purple Sand-piper.}

Very rare along the shores of the Atlantic in New Jersey, having never obtained but two specimens.

Tringar Alpina, rar. Americana.-Cas.

\section{Red-backed Sand-piper.}

Very abundant along the coast of New Jersey in Spring and Autumn. Have found it in September in Iowa in large flocks, going South.

$$
\text { Tringa Maculata-Vieill. }
$$

Jack Snipe.

I have often met with this bird when shooting Wilson's Snipe. It is generally found in pairs 
about April, and springs from the ground much the same as Wilson's Snipe. Often deceives the hunter.

$$
\text { Tringer Hilsomit-_inttull. }
$$

\section{Least Sand-piper.}

Very abundant on the shores of New Jersey, feeding on the meadows in the salt ponds, also in lowa along the sloughs. I think it breeds West, for I have seen it there in July on the prairies.

\section{Tringer Bonapartii.-Schleget.}

\section{Bonaparte's Sand-piper.}

This bird is rather rare to me. Have never met but three specimens.

$$
\text { Calidris Irentia-Illiger. }
$$

\section{Sanderling.}

Very common along the Jersey coast. Never found it breeding.

$$
\text { Evenutes, Petrificatus-Ill. }
$$

\section{Semipalmated Sand-piper.}

Very abundant along the shores of the Atlantic in Cape May county, New Jersey.

\section{Gambetta Mclandeuca.-Bonap.}

\section{Tell-tale; Stone Snipe.}

This bird is sometimes very abundant along the Delaware River in the month of May; but never but a few days. It makes its appearance 
in Iowa about the Ioth of May; remains all Summer. Never found it breeding.

\section{Yellow Legs.}

\section{Gambetta Flavipes.-Bonap.}

Very abundant along the sea coast in Autumn from New York south to Georgia. Very plenty in Iowa in the month of May, where it breeds. Four eggs. Nests on the ground.

$$
\text { Rhyacophilus Solitarizs.-Bonap. }
$$

\section{Solitary Sand-piper.}

This bird frequents swamps in timbered land. Have found it in the mountains of Pennsylvania and west to Iowa. I have found it breeding in May, It makes its appearance in April, and commences to lay about the last of the month. Found its nest on the first of May, with two eggs. It lays four generally. Have found several nests with four.

\section{Tringoides Macularius.-Gray.}

\section{Spotted Sand-piper.}

Very abundant from Delaware to Maine. Never found but one specimen as far west as Iowa.

\section{Field Plover.}

Actiturus Bartramius.-Bonap.

Very abundant in Iowa and Minnesota, where it breeds during the month of May. It leaves 
West with its young in the month of August, as soon as the wheat is cut. I never found it plenty in Pennsylvania. Found one specimen on Key West, Florida.

\section{Tryngites Rufesccuss-Cab.}

\section{Buff-breasted Sand-piper.}

This is a very rare bird in full plumage. I have never met with but one specimen in that stage.

$$
\text { Limosa Fedoa.-Ord. }
$$

\section{Marbled Godwit.}

Is very abundant along the seashore in $\mathrm{Au}$ tumn. When migrating they breed in large numbers in Iowa and Minnesota. I found them in Winter, in Georgia. Eggs four.

\section{Limosa Hudsonicus.}

\section{Hudson Godwit.}

I found this bird breeding in Winnebago Co., Iowa. Never met with it on the coast. Eggs four.

\section{Numenius Longirostris.-Wils.}

\section{Long-billed Curlew.}

Very abundant along the sea coast from New York to Georgia, and winters West to Iowa, where it breeds in May. Eggs four.

Numenizes Hudsonicus.-Latham.

\section{Hudsonian Curlew.}

Found it on the salt meadows of Cape May, in September, sometimes in great numbers. 


\section{8}

Some seasons I have found it in the month of May.

\section{Numunius Borealis-Latham.}

\section{Esquimaux Curlew.}

Found along the seashore from New York to Cape May, New Jersey. I have found it in Iowa in May, migrating westward.

$$
\text { Rallus Elegans. - Hud. }
$$

\section{Marsh Hen.}

I have found this bird along the Delaware river when shooting rail, $P$. Carolina, in September, also in April, when snipe shooting on the meadows below the city. Found it breeding in the same meadows, now in the city of Philadelphia. Also found it breeding in Iowa.

$$
\text { Rallus Crefitums.-Gm. }
$$

\section{Clapper Rail.}

Very abundant from South Carolina to New York, on the salt meadows.

$$
\text { Rallus I irginanus.-Linn. }
$$

\section{Virginia Rail.}

Not as numerous about the Delaware as others, but have found it breeding in the meadows below the city, and abundant in lowa. Remains West until the first frost. Eggs from eight to fourteen. 


\section{Porsana Carolina. - Iicill.}

\section{Common Rail.}

Very abundant in Autumn along the marshes of the Delaware River. Very abundant in Iowa and Wisconsin, breeding in great numbers around the slough. I have seen them as thick as black birds. Eggs eight to fourteen.

$$
\text { Porantr Famricusis.--Cassin. }
$$

\section{Little Black Rail.}

Very rare. I found this bird breeding at Beesley's Point, New Jersey. Also found it near Mount Holly, New Jersey. Eggs eight.

\section{Porsina Noneboraconsis.}

\section{Yellow Rail.}

Found in the wet meadows in Spring, and on the marshes in Autumn. Breeds in Iowa, where I found its nest with eight eggs.

\section{Grex Pratensis-Bechst.}

\section{Corn-crake.}

I was fortunate enough to obtain a specimen of this bird, while shooting wood-cock in June, in the meadows above Bordentown, N. J. This specimen is now in the Academy of Natural Science, of Philadelphia. I also obtained another specimen, shot in the meadows below Salem, N. J., in the month of August. 
Fulica Americana.-Gmelin.

Coot.

Very abundant from Georgia to New York, and from the Atlantic to Minnesota, where it breeds in great numbers. Eggs from eight to sixteen.

\section{Gallinula Galeata-Bonap.}

\section{Florida Gallinule.}

Often found upon the meadows along the Delaware River, and west to Iowa, where it breeds. Eggs from eight to twelve.

Gallinula Martinica.-Lath. .

\section{Purple Gallinule.}

Sometimes found on the marshes of the Delaware in Autumn. I have found it breeding in Iowa in the month of June Eggs eight.

\section{Cygnus Americanus.- Sharpless.}

\section{American Swan.}

I obtained one specimen on the Chesapeake Bay, when duck-shooting near Turkey Point. Rare.

Cygmus Buccinator-Rich.

\section{Trumpeter Swan.}

Found very plenty on the Chesapeake Bay, in Winter. Some seasons I have obtained two specimens on the Delaware River. It breeds in Iowa. 
Anser Hyperboreus.-Pallas.

\section{Snow Goose.}

I found this goose at Chingateague, Virginia, one Winter, very plenty. It is called the White Brant there. I also found it in Iowa, where they pass in great numbers in April, stopping to feed on the grain fields.

\section{- Inser Gambelii.-Hartlaub.}

\section{White-fronted Goose.}

Very abundant in Iowa about the last of March, returning in November, when they stop to feed on the wheat.

\section{Bernicla Canadensis.-Boie.}

\section{Canada Goose.}

Very abundant in Spring and Fall, on the Delaware below Bombay Hook, and at Hog Island, Virginia. Breeds in Iowa and Minnesota in April, and as late as May.

\section{Bernicla Brenta.-Steph.}

\section{Brant.}

Very abundant along the sea coast from Long Island to Cape May.

$$
\text { Bernicla Nigricans.-Cassin. }
$$

\section{Black Brant.}

I procured one specimen at Barnegat, New Jersey, and one from Beesley's Point, New Jersey, being the only two specimens I ever met with. 
- Hurs Boschas.-Linn.

\section{Mallard.}

Very abundant from Georgia to Maine, and as far West as Iowa to Minnesota, where it breeds.

$$
\text { thas Obscura.-Gm. }
$$

\section{Black Duck.}

Common on the salt marshes from Virginia to Long Island. I found them breeding below Great Egg Harbor, New Jersey. Eggs two.

$$
\text { Dafila Hcutu.-Fennzs. }
$$

\section{Sprig-tail; Pin-tail.}

This duck makes its appearance in Spring, when the ice breaks up, remaining but a few days, and then renews its flight northward. I found a few breeding in Iowa. Eggs eleven.

Vettion Carolininsis. Bairol.

\section{Green-winged Teal.}

Arrives early in the Spring and leaves in April. I have found them breeding in Iowa in the month of May.

\section{English Teal.}

$$
\text { Vittion Creccr.-Sintp. }
$$

I found two specimens in the year 1874 , in Winnebago county, lowa. Rare.

\section{Blue-winged Teal.}

$$
\text { Querqueduler Discors.-Stcph. }
$$

Arrives in March and leaves in May. I found them very numerous in Iowa and Minnesota. 
They are very numerous. I have collected eggs and hatched them out under a chicken, and tried to tame them, but could not succeed; they would run for the lake as soon as they could get out of the pen. Eggs eleven.

\section{Spatula Clypeata.-Boie.}

\section{Shoveller.}

Very abundant in Virginia in the winter. Rare in Pennsylvania and abundant in Iowa, where it breeds. Eggs eight to eleven.

\section{Chaulclasmus Striperus.-Gray'.}

\section{Gadwall.}

Not common in Delaware. They winter in Virginia. Breeds in Minnesota. Eggs eight. Hariar Amiricana.-Stephens.

\section{Baldpate.}

Found on the Susquehanna flats in Autumn. Common in April along the Delaware.

$$
\text { Marca l'cuelopi-Bonap. }
$$

\section{Widgeon.}

Rare. Have found two specimens, which I shot in Maryland on the Patuxent Bay, in 1874. I had one sent me in 1875 .

$$
\text { Aix Sponser.-Boie. }
$$

\section{Summer Duck.}

This duck is much sought after for its beauty. Not fit for table use. Breeds in hollow trees 
along the creeks and lakes in Iowa. Found them some seasons very plenty on the marshes of the Delaware River. .Not rare.

$$
\text { Fulix Marila-Dirird. }
$$

\section{Greater Black-head.}

Abundant on the Susquehanna flats in November and March. Found along the Delaware River and Mest to Minnesota. Breeds. I found one breeding in Iowa in 1874. Eggs eight. Shot the parent bird in Lime Creek.

\section{Little Black-head.}

$$
\text { Fitlix Affinis.-Baird. }
$$

Common on the Delaware and Susquehanna Rivers. Breeds in Iowa and Minnesota. Eggs nine.

$$
\text { Fulix Colluris.-Baird. }
$$

\section{Ring-necked Duck.}

Not common; found in company with the $F$. Affmis, and met with often on the Delaware River.

\section{Red-head.}

Aythya Amiricana.-Bonap.

Abundant on the Chesapeake in Winter, and as far South as North Carolina. I found it in Iowa and found it breeding in Minnesota, above Fergus Falls. Eggs eight.

\section{Canvass-back.}

$$
\text { Aythya I'allisucria.-Bonap. }
$$

Common on the flats of the Susquehanna and as far South as Charleston, South Carolina, in 
Winter. I have found it breeding on the lakes in Minnesota above St. Paul. Eggs eight to ten.

$$
\text { Buccplala tmericana-Baird. }
$$

\section{Golden Eye.}

Not rare. Found on the mill dams through New Jersey and south to Virginia in Winter. Breeds in hollow trees near rivers, creeks, lakes and ponds. I'ound as far west as lowa. Eggs nine.

$$
\text { Buccphuld Albeola.-Baird. }
$$

\section{Butter Ball.}

Common from Virginia to New York and along the Jersey shore, and thoroughfare, and on the Delaware. I found it breeding in the mountains of New York, in Delaware County. Breeds in hollow trees. Eggs eight.

$$
\text { Harelda Glacialis.-Leach. }
$$

\section{South Southerly.}

This cluck is found sometimes on the Delaware in large quantities, some seasons. It is very common at Barnegat, and south to $\mathrm{Hog}$ Island, Virginia.

$$
\text { Melanetta I'clietina.-Baird. }
$$

\section{Velvet Duck.}

I found this duck in the inlet at Atlantic City and Corson's Inlet. You can seldom get near 
enough to shoot them, as they keep out beyond the surf. Not common.

\section{Pelionctta Perspicillata.-Kinup.}

\section{Surf Duck.}

Common but hard to shoot, on account of its keepins out in the surf, where the sunner cannot get. On a stormy day they can be found in the inlet. I found a flock in the Delaware River once and killed several at one shot.

\section{Oidemia Amoricana.- Mánins.}

Scoter.

Rare; not often met with. Found from Barnegat to Cape May, New Jersey. Never killed but three specimens.

Simateria Hollissina-Leach.

\section{Eider Duck.}

Never met with th's lird but on one occasion, when I obtained four good full-plumaged birds at Barnegat in New Jersey in the month of February.

Somatoric Spectabilis.-Leach.

\section{King Eider.}

Two specimens of this bird were obtained at Es.r. Harbor, New Jersey, both being males. The female bird I obtained at Tackertown. It is often found in New York market. 
Erismatura Rubida.-Dionap.

\section{Ruddy Duck.}

Not common. Found from Delaware to New York, and west to Iowa, where it breeds. Egrs eight.

\section{Herents Americamus._- Cass.}

\section{Sheldrake.}

I have often killed this cluck on the Delaware, south of Chester, Pa., and north to Delaware County, New York, where I found it breeding, and observed it carrying the young from a hollow tree, and depositing them in a pond near the river. I have also shot it in Iowa. Breeds in Minnesota. Not common.

$$
\text { Morgus Semator-Linn. }
$$

\section{Red-breasted Merganser.}

Not common. I have found it on the Delaware, and as far soutl as Virginia.

\section{Lophodytes Cucullatus.-Reich.}

\section{Hooded Merganser.}

Found in the Winter as far south as Virginia; also along the Delaware River and west to Iowa, where I found it breeding. Nest in hollow trees. Egss eight. Not rare.

$$
\text { Pclcomus Fuscus.-Iinn. }
$$

\section{Brown Pelican.}

It is very abundant at Key West, Florida, and 
breeds in great numbers at Snake Key, on mangrove bushes. Eggrs two.

$$
\text { Pelicanus Erythroringuchus-Gm. }
$$

\section{American Pelican.}

Very abundant in Iowa and Minnesota, where it breeds. I found a large flock in Beaver Lake, Minnesota, in May, 1872, and obtained three specimens.

\section{Sula Bassana.-Briss.}

\section{Gannet.}

I obtained one specimen on the steamboat, Charleston Harbor, it being blown on board by a storm. Found it breeding on Florida Keys.

$$
\text { Tachypetes slquilu. I I icillot. }
$$

\section{Man-of-war Bird.}

Very abundant on the Keys of Florida, flying in large flocks along the beach.

\section{Griculus Carbo.-Grav.}

\section{Common Cormorant.}

Very abundant in Florida. I have seen acres of them off of the town of Key W'est. Often found on the Delaware. Called by gunners Crow Groose, as far west as Iowa.

$$
\text { Gruculus Cincinnatus.-Gruy'. }
$$

\section{Tufted Cormorant.}

Found one specimen of this bird on Lime Creek, Winnebago County, lowa, in 1875 . 
Thalassidroma Hitsoni.-Bonap.

\section{Wilson's Petrel.}

I found this bird on one occasion in the Delaware Bay, near Lewistown, Delaware, the weather being very clear and calm. I shot one when the Captain told me there would a storm lefore we reached the land. I laughed at him, but to my surprise in less than half an hour I witnessed one of the worst blows I ever saw, and we were obliged to run into a creek for shelter.

\section{Thalassidroma Pclagica.-Bonap.}

\section{Mother Cary's Chicken.}

I shot one of these birds on the Schuylkill River below the Market Street bridge, Philadelphia. There was a large flock of them and when I shot the one the others made off. They must have been blown in by a heary storm.

Stercorarius Pomarinus. - Tomm.

\section{Pomarine Skua.}

In October, I 859 , while gunning on the meadows below Broad Street, Philadelphia, I shot at a tock of Black-tellied Plover and killed three birds, and upon examination found one of them to be S. I'mm rmms. Supposed it to be a straggler.

$$
\text { Larus .Marinus.-Limn. }
$$

\section{Great Blacked-backed Gull.}

I obtained one specimen of this Gull at Barnegat, New Jersey. I have seen specimens shot on the Delaware River. 
Lanus -Irecontatus-Brann.

\section{Herring Gull.}

Very abundant in Winter on the Delaware River, and on the Jersey coast. I saw them in the Bay of Funcly, very thick. They breed on Gran-Manan.

\section{Larus Delawarensis. - Ord.}

\section{Ring-billed Gull.}

Found on the Delaware River in the month of March. Rare.

Chroicocephalus Atriciller.-Lim.

\section{Laughing Gull.}

Very abundant along the Jersey coast in the month of May, where they breed on salt meadows, making their nest of drift weed and sea weeds. I have found them breeding on what is called Gull Island, in great numbers, below Seaville, New Jersey.

\section{Chroicocephalus Philadelphia.}

\section{Bonaparte's Gull.}

Not common. Found on the Delaware in April and October, and west to Rice Lake, Iowa.

Sterna Regia-Gambel.

\section{Royal Tern.}

Very abundant on the Tortugus Island, Florida, and breeds on the Keys of Florida. I 
have seen them in great numbers. I have two specimens in my collection.

Sterna Fuliginusix.-Gm.

\section{Sooty Tern.}

Common on the Keys of Florida and the Tortugas, where it breeds in large numbers. I have two specimens in my collection.

Sterna Hrancin.-Wils.

\section{Marsh Tern.}

I found it on the Seven-Mile Beach, New Jerscy, breeding in company with several other species. Eggs four, laid on the bare sand.

\section{Stema Wilseni-Bonap.}

\section{Wilson's Tern.}

Very abundant along the Jersey coast, where it breeds. Found on the Delaware some seasons, and west to Lake Erie. Exys four. Lays on the bare sand of the sand hills, or dry flats on the seashore, where the ticle cannot reach them.

\section{Stcrne Forsteri- Vutt.}

\section{Forster's Tern.}

Not common. Found on the shore of New Jersey in company with S. IFilsomii, west to Iowa.

Stcrnar Paradisea.-Brntn.

\section{Roseate Tern.}

Found along the coast from Virginia to New Jersey. Not common. 
Sterna Frenata.-Gamble.

\section{Least Tern.}

Abundant along the Jersey coast. Breeds on the flat sands on the Seven Mile Beach, New Jersey. I found it very plenty on Clear Lake, Iowa. Breeds on the drift along the shore of the lake.

\section{Hydrochclidon Plambea.-Wits.}

\section{Short-tailed Tern.}

Found in Autumn on the Delaware River, in immature plumage. Very abundant in Iowa and Minnesota on the sloughs and lakes, breeding in large numbers.

$$
\text { Anous Stolidus.-Leach. }
$$

\section{Noddy Tern.}

Found from the Florida Keys to the Tortugas, where it breeds. I have two specimens in $m y^{\prime}$ collection.

\section{Black Skimmer.}

$$
\text { Rhynchops Nigna - Linn. }
$$

Found from Peck's Beach, Cape May, to Virginia. Breeds on all the beaches in Cape May county, New Jersey. Eggs four. Nest on the sand bills.

$$
\text { Colymbus Torquates.-Brum. }
$$

\section{Loon.}

Common from Florida to Maine, and west from the Atlantic to Minnesota. Breeds on the 
lakes. The rest is made upon an old muskrat inmetimes floating from one part of the noust, su other, according to the wind. I have often seen this bird in the Gulf stream of Georgia. Eggrs two.

\section{Colymbins: Septentrionalis.-Limn.}

\section{Red-throated Diver.}

It is often found in Winter on the Delaware River. I have never procured but one bird in full plumage in Spring. Rare.

\section{Podiceps Griscigenu-Gray.}

\section{Red-necked Grebe.}

It is often found in Winter on the Delaware River, and south to Virginia. Its plumage is very rare in Spring, and common on the lakes above St. Paul, Minnesota, where it breeds. Eggs from eight to eleven.

\section{Podiceps Cristatus. - Lath.}

\section{Crested Grebe.}

Found on the Delaware River, south to Cape May, and west to Minnesota. Breeds on the lakes. Eggs six to ten.

$$
\text { Podiceps Cornutus._Latham. }
$$

\section{Horned Grebe.}

Not common. Found from New Jersey to Iowa, where it breeds. Eggs eight to twelve, and covered over with mud and reeds. 


$$
\text { I'odilymbis Podiceps.-Larior: }
$$

\section{Carolina Grebe.}

Abundant from Virginia to Mi Breedsal to Minnesota. Breeds very abu... ant in all the sloughs and lakes in Iowa. Eggs from eight to thirteen.

$$
\text { Lrier Grolle.-Latham. }
$$

\section{Black Guillemot.}

Some winters it is found along the Jersey coast as far as Cape May. I obtained two specimens at Eggr Harbor, in winter plumage.

$$
\text { Crici-lrow-Pallas. }
$$

\section{Thick-billed Guillemot.}

Not common. Some winters it is found at Tuckertown and Long Branch, New Jersey. I have a specimen in my collection.

$$
\text { Herinulus. Hlle.-Tieillot. }
$$

\section{Sea Dove.}

I found two specimens of this bird at Atlantic City, in the inlet, in November, I874. 





